\title{
Mineralogy of Silicate-Natrophosphate Immiscible Inclusion in Elga IIE Iron Meteorite ${ }^{\dagger}$
}

\author{
Victor V. Sharygin ${ }^{1,2}$ (D) \\ 1 V.S. Sobolev Institute of Geology and Mineralogy, Siberian Branch of the RAS, 3 Acad. Koptyuga pr., \\ 630090 Novosibirsk, Russia; sharygin@igm.nsc.ru \\ 2 ExtraTerra Consortium, Institute of Physics and Technology, Ural Federal University, 19 Mira str., \\ 620002 Ekaterinburg, Russia \\ + The paper was presented at the 81st Annual Meeting of the Meteoritical Society in Moscow, Russia, \\ 22-27 July 2018.
}

Received: 7 April 2020; Accepted: 11 May 2020; Published: 13 May 2020

\begin{abstract}
Rare type of silicate inclusions found in the Elga iron meteorite (group IIE) has a very specific mineral composition and shows silicate $(\approx 90 \%)$-natrophosphate $(\approx 10 \%)$ liquid immiscibility due to meniscus-like isolation of Na-Ca-Mg-Fe phosphates. The $3 \mathrm{~mm}$ wide immiscible inclusion has been first studied in detail using optical microscopy, scanning electron microscopy, electron microprobe analysis and Raman spectroscopy. The silicate part of the inclusion contains fine-grained quartz-feldspar aggregate and mafic minerals. The relationships of feldspars indicate solid decay of initially homogenous K-Na-feldspar into albite and K-feldspar with decreasing of temperature. Some mafic minerals in the silicate part are exotic in composition: the dominant phase is an obertiite-subgroup oxyamphibole (amphibole supergroup), varying from ferri-obertiite $\mathrm{NaNa}_{2} \mathrm{Mg}_{3} \mathrm{Fe}^{3+} \mathrm{Ti}\left[\mathrm{Si}_{8} \mathrm{O}_{22}\right] \mathrm{O}_{2}$ to hypothetical $\mathrm{NaNa}_{2} \mathrm{Mg}_{3} \mathrm{Fe}^{2+}{ }_{0.5} \mathrm{Ti}_{1.5}\left[\mathrm{Si}_{8} \mathrm{O}_{22}\right] \mathrm{O}_{2}$; minor phases are the aenigmatite-subgroup mineral (sapphirine supergroup) with composition close to median value of the $\mathrm{Na}_{2} \mathrm{Fe}^{2+}{ }_{5} \mathrm{TiSi}_{6} \mathrm{O}_{18} \mathrm{O}_{2}-\mathrm{Na}_{2} \mathrm{Mg}_{5} \mathrm{TiSi}_{6} \mathrm{O}_{18} \mathrm{O}_{2}$ join, orthopyroxene (enstatite), clinopyroxene of the diopside $\mathrm{Ca}(\mathrm{Mg}, \mathrm{Fe}) \mathrm{Si}_{2} \mathrm{O}_{6}-$ kosmochlor $\mathrm{NaCrSi}_{2} \mathrm{O}_{6}-\mathrm{Na}\left(\mathrm{Mg}, \mathrm{Fe}_{0.5} \mathrm{Ti}_{0.5} \mathrm{Si}_{2} \mathrm{O}_{6}\right.$ series and chromite. The alteration phases are represented by Fe-dominant chlorite, goethite and hydrated $\mathrm{Na}_{2} \mathrm{O}$-rich (2.3-3.3 wt.\%) Fe-phosphate close to vivianite. Natrophosphate part consists of aggregate of three orthophosphates (brianite, czochralskiite, marićite) and minor Na-Cr-Ti-clinopyroxene, pentlandite, rarely taenite. Czochralskiite $\mathrm{Na}_{4} \mathrm{Ca}_{3} \mathrm{Mg}\left(\mathrm{PO}_{4}\right)_{4}$ is rich in $\mathrm{FeO}$ (2.3-5.1 wt.\%) and $\mathrm{MnO}(0.4-1.5$ wt.\%). Brianite $\mathrm{Na}_{2} \mathrm{CaMg}\left(\mathrm{PO}_{4}\right)_{2}$ contains $\mathrm{FeO}(3.0-4.3$ wt. $\%)$ and $\mathrm{MnO}(0.3-0.7$ wt. $\%)$ and marićite $\mathrm{NaFe}\left(\mathrm{PO}_{4}\right)$ bears $\mathrm{MnO}$ (5.5-6.2 wt.\%), $\mathrm{MgO}$ (5.3-6.2 wt.\%) and $\mathrm{CaO}(0.5-1.5 \mathrm{wt} . \%)$. The contact between immiscible parts is decorated by enstatite zone in the silicate part and diopside-kosmochlor clinopyroxene zone in the natrophosphate ones. The mineralogy of the studied immiscible inclusion outlines three potentially new mineral species, which were first identified in meteorites: obertiite-related oxyamphibole $\mathrm{NaNa}_{2} \mathrm{Mg}_{3} \mathrm{Fe}^{2+}{ }_{0.5} \mathrm{Ti}_{1.5}\left[\mathrm{Si}_{8} \mathrm{O}_{22}\right] \mathrm{O}_{2}, \mathrm{Mg}$-analog of aenigmatite $\mathrm{Na}_{2} \mathrm{Mg}_{5} \mathrm{TiSi}_{6} \mathrm{O}_{18} \mathrm{O}_{2}$ and Na-Ti-rich clinopyroxene $\mathrm{Na}\left(\mathrm{Mg}, \mathrm{Fe}_{0.5} \mathrm{Ti}_{0.5} \mathrm{Si}_{2} \mathrm{O}_{6}\right.$.
\end{abstract}

Keywords: silicate-natrophosphate immiscibility; obertiite; aenigmatite; kosmochlor; brianite; czochralskiite; marićite; Elga meteorite; IIE iron; Yakutia

\section{Introduction}

The Elga iron meteorite (group IIE) is a fine-grained octahedrite with up to 15 vol. $\%$ silicate inclusions and with local zones of shock metamorphism [1-20]. Silicate-bearing iron meteorites represent about $4 \%$ of all iron meteorites. In general, they are important for understanding metal-silicate partitioning in processes related to the formation and evolution of asteroids and terrestrial planets 
in the early solar system. At present day, silicate-bearing iron meteorites were described within the following chemical groups: IAB (12\% of total), IIE (50\%) and IVA (5\%); silicate inclusions were also reported for 8 ungrouped iron meteorites [15]. The mineralogy of silicate inclusions indicates the peculiarities of metal-silicate relations in meteorite parental bodies. The exotic mineral composition of some silicate inclusions may reflect local specific conditions within parental bodies. This paper is devoted to the mineralogy of a silicate inclusion with specific minerals and silicate-natrophosphate immiscibility found in the Elga meteorite.

\section{History of Finding and Brief Review on Studies for the Elga Meteorite}

The Elga meteorite was found on August 28, 1959, at the Razvedchik gold field in the basin of the Elga River, a large left-hand tributary of the Indigirka River in its upper reaches, in the territory of Yakutia $\left(64^{\circ} 42^{\prime} \mathrm{N}, 141^{\circ} 12^{\prime} \mathrm{E}\right)$. The meteorite was found when gold-bearing sand was washed, with the sand recovered from a production mine in the valley of the Promezhutochnyi Stream, a right-hand tributary of the Elga River. The meteorite was found in pebble material lifted from a depth of $20 \mathrm{~m}$. The detailed description of the finding is given in $[2,14]$.

The meteorite is of irregular, slightly angular morphology, and its natural surface is rounded and locally displays a thin platy fabrics and regmaglypt surface topography. The upstanding fine-flow surface areas are of steel-gray color, whereas "depressions" are covered with a black film and, locally, rust-brown material (up to $3 \mathrm{~mm}$, Figure 1). The general mass of the sample was $28.8 \mathrm{~kg}$. The main mass of the Elga meteorite (type specimen-10.5 kg plus some smaller cut-offs of the working collection, $449 \mathrm{~g}$ and $79.8 \mathrm{~g}$ ) is now on display in the meteorite collection of the Central Siberian Geological Museum (CSGM) in the V.S. Sobolev Institute of Geology and Mineralogy (IGM, SB RAS), Novosibirsk, Russia (registration number I-1155/204-24, Figure 1). Fragments from the working collection were used for detailed mineralogical investigations $[5,9,12,13,17,20]$. A large cut-off fragment (887.5 g) of the meteorite was transferred to the Meteorite Committee of the USSR Academy of Sciences (now in the Vernadsky Institute of Geochemistry and Analytical Chemistry, GEOKHI RAS, Moscow, Russia) and its cut-offs were also used for studies [8,10,11,14-16,18-20]. Smaller cut-offs of the Elga meteorite are also deposited in the meteorite collection of the Museum in the Institute of Diamond and Precious Metal Geology, SB RAS, Yakutsk (126.7 g) and, possibly, in other geological museums in Russia.
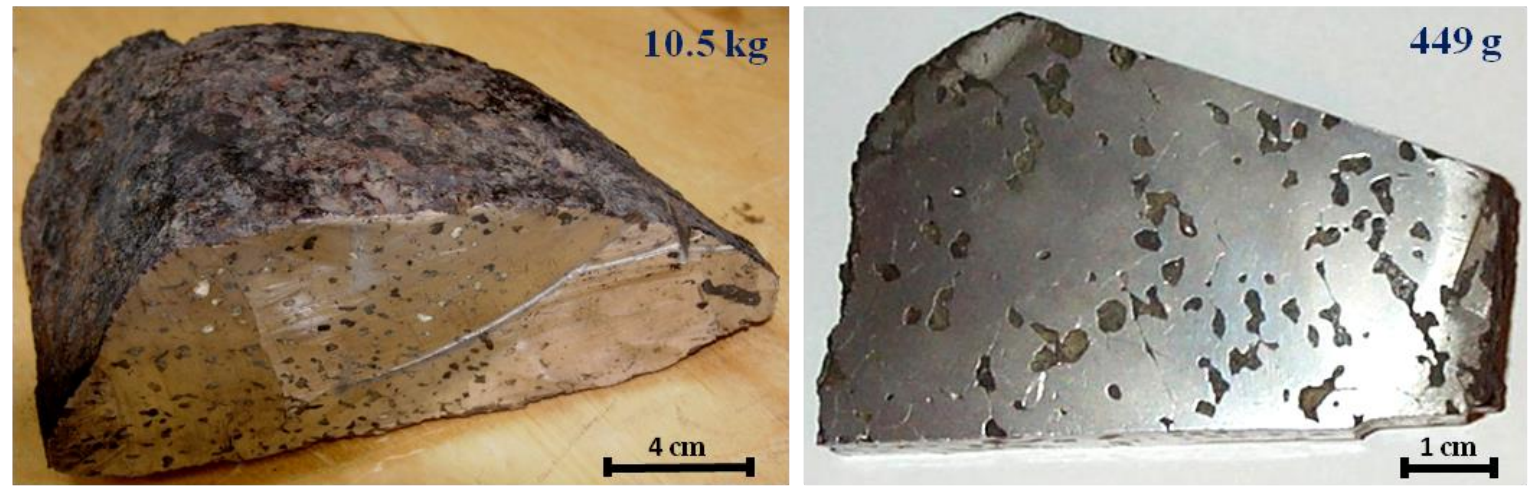

Figure 1. General view of the Elga iron meteorite (IIE) and a cut-off with silicate inclusions. Type specimen from CSGM IGM, SB RAS, Novosibirsk.

The Elga meteorite is a fine-grained octahedrite with numerous (up to 15 vol.\%) rounded silicate inclusions (up to a few millimeters in size) [1]. The texture and composition of the metal and silicate inclusions indicate that the meteorite shows traces of secondary melting caused by shock metamorphism [1,5,8-20]. The chemical composition of the metallic constituent is as follows: $90.51 \mathrm{wt} . \%$ $\mathrm{Fe}, 8.38$ wt.\% Ni, 0.64 wt.\% Co, 0.46 wt.\% P and 100 ppm Cu [3,7]. Based on concentrations of Ni (7.98 wt.\%), Ga (24.1 ppm), Ge (71.8 ppm) and Ir (4.1 ppm), the meteorite was assigned to the group 
IIE [4]. The pattern for trace siderophile elements in the metal of the IIE meteorites suggests that they were produced during the first stages of unequilibrated crystallization of melts from an $\mathrm{H}$ chondritic source in a closed system $[10,15,18]$.

The silicate inclusions in the Elga meteorite are rounded or oval; sizes-1-5 mm, sometimes up to 10-15 mm. They strongly vary in texture, chemistry and mineral composition. Most inclusions are gray-green and consist of glass (45-70 vol.\%), diopside (25-50 vol.\%) and enstatite (1-5 vol.\%), rarely phosphates (fluorapatite, merrillite, panethite), olivine, chromite and rutile [5,8,9,11-13,15]. In general, silicate inclusions in this meteorite are morphologically and chemically similar to those in other iron meteorites of the group IIE (for example, Kodaikanal, Weekeroo Station and Colomera) [5,8-13,15]. The Elga silicate inclusions were previously subdivided into five types [8]. The recent studies for silicate inclusions gave more abundant information about their mineralogy, composition and geochemistry $[9,11-13,17,18]$.

In addition to previous data, the numerous petrographic and mineralogical evidences about local impact melting in the meteorite (both in metal and in silicate inclusions) were outlined in recent publications $[9,10,13,18-20]$. However, the pressure interval during the impact melting event in the Elga meteorite is still discussible. It is suggested that pressure may be up to 12-15 GPa (by the presence of tuite in silicate inclusions) and even up to $20 \mathrm{GPa}$ (by the presence of the $\mathrm{Fe}_{3} \mathrm{P}-\mathrm{Fe}_{3} \mathrm{~S}$ solid solution in quenched Fe-Ni-P-S melt pockets) $[13,20]$. Unfortunately, the appearance of the above mineral phases in the Elga meteorite is questionable: identification of tuite was supported only by Raman spectroscopy [13], whereas the real existence and homogeneity of the proposed $\mathrm{Fe}_{3}(\mathrm{P}, \mathrm{S})$ phase were not proven [20].

The mineralogy and geochemistry of the meteorite and its features of impact metamorphism were described in detail [1-22]. The mineralogical data for the Elga meteorite are summarized in Table 1. This publication provides a detailed description of the mineralogy for an Elga silicate inclusion with silicate-natrophosphate immiscibility. This is a new and rare type of silicate inclusions, which was recently found in the Elga meteorite and which drastically differs from other types in unique mineralogy $[12,13,17]$.

Table 1. List of mineral phases and glasses found in the Elga meteorite.

\begin{tabular}{|c|c|c|c|}
\hline Mineral & Formula & Mineral & Formula \\
\hline Graphite & $\mathrm{sp}^{2}-\mathrm{C}$ & Rutile & $\mathrm{TiO}_{2}$ \\
\hline Iron (kamacite) & $\alpha-(\mathrm{Fe}, \mathrm{Ni})$ & Chromite & $\mathrm{FeCr}_{2} \mathrm{O}_{4}$ \\
\hline Taenite & $\gamma-(\mathrm{Fe}, \mathrm{Ni})$ & Magnetite & $\mathrm{FeFe}_{2} \mathrm{O}_{4}$ \\
\hline Tetrataenite & $\mathrm{FeNi}$ & Trevorite & $\mathrm{NiFe}_{2} \mathrm{O}_{4}$ \\
\hline Schreibersite & $(\mathrm{Fe}, \mathrm{Ni})_{3} \mathrm{P}$ & Ilmenite & $\mathrm{FeTiO}_{3}$ \\
\hline "Ferro-melliniite" & $(\mathrm{Fe}, \mathrm{Ni})_{4} \mathrm{P}$ & Armalcolite & $(\mathrm{Mg}, \mathrm{Fe}) \mathrm{Ti}_{2} \mathrm{O}_{5}$ \\
\hline Troilite & $\mathrm{FeS}$ & Quartz & $\mathrm{SiO}_{2}$ \\
\hline Millerite & $\mathrm{NiS}$ & Forsterite & $(\mathrm{Mg}, \mathrm{Fe})_{2} \mathrm{SiO}_{4}$ \\
\hline Pentlandite & $(\mathrm{Fe}, \mathrm{Ni})_{9} \mathrm{~S}_{8}$ & Enstatite & $(\mathrm{Mg}, \mathrm{Fe})_{2} \mathrm{Si}_{2} \mathrm{O}_{6}$ \\
\hline Fluorapatite & $\mathrm{Ca}_{5}\left(\mathrm{PO}_{4}\right)_{3} \mathrm{~F}$ & Diopside & $\mathrm{Ca}(\mathrm{Mg}, \mathrm{Fe}) \mathrm{Si}_{2} \mathrm{O}_{6}$ \\
\hline Merrillite & $\mathrm{Ca} 9 \mathrm{NaMg}\left(\mathrm{PO}_{4}\right)_{7}$ & Kosmochlor & $\mathrm{NaCrSi}_{2} \mathrm{O}_{6}$ \\
\hline Tuite & $\mathrm{Ca}_{3}\left(\mathrm{PO}_{4}\right)_{2}$ & "Na-Ti-clinopyroxene" & $\mathrm{Na}(\mathrm{Mg}, \mathrm{Fe})_{0.5} \mathrm{Ti}_{0.5} \mathrm{Si}_{2} \mathrm{O}_{6}$ \\
\hline Panethite & $(\mathrm{Na}, \mathrm{Ca}, \mathrm{K})_{2}(\mathrm{Mg}, \mathrm{Fe})_{2}\left(\mathrm{PO}_{4}\right)_{2}$ & Ferri-obertiite & $\mathrm{NaNa}_{2} \mathrm{Mg}_{3} \mathrm{Fe}^{3+} \mathrm{Ti}\left[\mathrm{Si}_{8} \mathrm{O}_{22}\right] \mathrm{O}_{2}$ \\
\hline Czochralskiite & $\mathrm{Na}_{4} \mathrm{Ca}_{3} \mathrm{Mg}\left(\mathrm{PO}_{4}\right)_{4}$ & "Titan-obertiite" & $\mathrm{NaNa}_{2} \mathrm{Mg}_{2} \mathrm{Fe}^{2+}{ }_{0.5} \mathrm{Ti}_{1.5}\left[\mathrm{Si}_{8} \mathrm{O}_{22}\right] \mathrm{O}_{2}$ \\
\hline Brianite & $\mathrm{Na}_{2} \mathrm{CaMg}\left(\mathrm{PO}_{4}\right)_{2}$ & Aenigmatite & $\mathrm{Na}_{2}\left(\mathrm{Fe}^{2+}, \mathrm{Mg}\right)_{5} \mathrm{TiSi}_{6} \mathrm{O}_{18} \mathrm{O}_{2}$ \\
\hline Marićite & $\mathrm{NaFe}\left(\mathrm{PO}_{4}\right)$ & "Magnesio-aenigmatite" & $\mathrm{Na}_{2}\left(\mathrm{Mg}, \mathrm{Fe}^{2+}\right)_{5} \mathrm{TiSi}_{6} \mathrm{O}_{18} \mathrm{O}_{2}$ \\
\hline Chladniite & $\mathrm{Na}_{2} \mathrm{Ca}(\mathrm{Mg}, \mathrm{Fe})_{7}\left(\mathrm{PO}_{4}\right)_{6}$ & Albite & $\mathrm{NaAlSi}_{3} \mathrm{O}_{8}$ \\
\hline "Na-Fe-Mg-phosphate" & $\mathrm{Na}_{2}(\mathrm{Fe}, \mathrm{Mn})(\mathrm{Mg}, \mathrm{Ca})\left(\mathrm{PO}_{4}\right)_{2}$ & K-feldspar & $\mathrm{KAlSi}_{3} \mathrm{O}_{8}$ \\
\hline "Na-Fe- $\mathrm{H}_{2} \mathrm{O}$-phosphate" & $\mathrm{Na}$-rich $\mathrm{Fe}^{2+}{ }_{3}\left(\mathrm{PO}_{4}\right)_{2} \cdot 8 \mathrm{H}_{2} \mathrm{O}$ & Chlorite (chamosite?) & $\mathrm{Fe}_{5} \mathrm{Al}\left[\mathrm{AlSi}_{3} \mathrm{O}_{10}\right](\mathrm{OH})_{8}$ \\
\hline Siderite & $(\mathrm{Fe}, \mathrm{Ni})\left(\mathrm{CO}_{3}\right)$ & Serpentine & $\mathrm{Fe}_{3} \mathrm{Si}_{2} \mathrm{O}_{5}(\mathrm{OH})_{4}$ \\
\hline Goethite & $\alpha-\mathrm{FeOOH}$ & Siliceous glass & $>70$ wt. $\% \mathrm{SiO}_{2}$ \\
\hline Hematite & $\mathrm{Fe}_{2} \mathrm{O}_{3}$ & Ca-Mg-Fe silicate glass & $40-45$ wt. $\% \mathrm{SiO}_{2}$ \\
\hline
\end{tabular}

Data are from [1,5,8-20] and from this work. The names in inverted commas mean poorly identified phases or potentially new mineral species. See also Figures S1-S14 from Supplementary data. The assumed phase of the $\mathrm{Fe}_{3} \mathrm{P}-\mathrm{Fe}_{3} \mathrm{~S}$ series [20] is not included here. The minerals in italics are first described for the Elga meteorite in this study. 


\section{Analytical Methods}

The polished cut-off $(35 \times 18 \times 3 \mathrm{~mm}$, Figure 2$)$ from the $449 \mathrm{~g}$ sample at CSGM IGM, SB RAS, Novosibirsk, was used for optical examination of the Elga meteorite in reflected light and other studies.
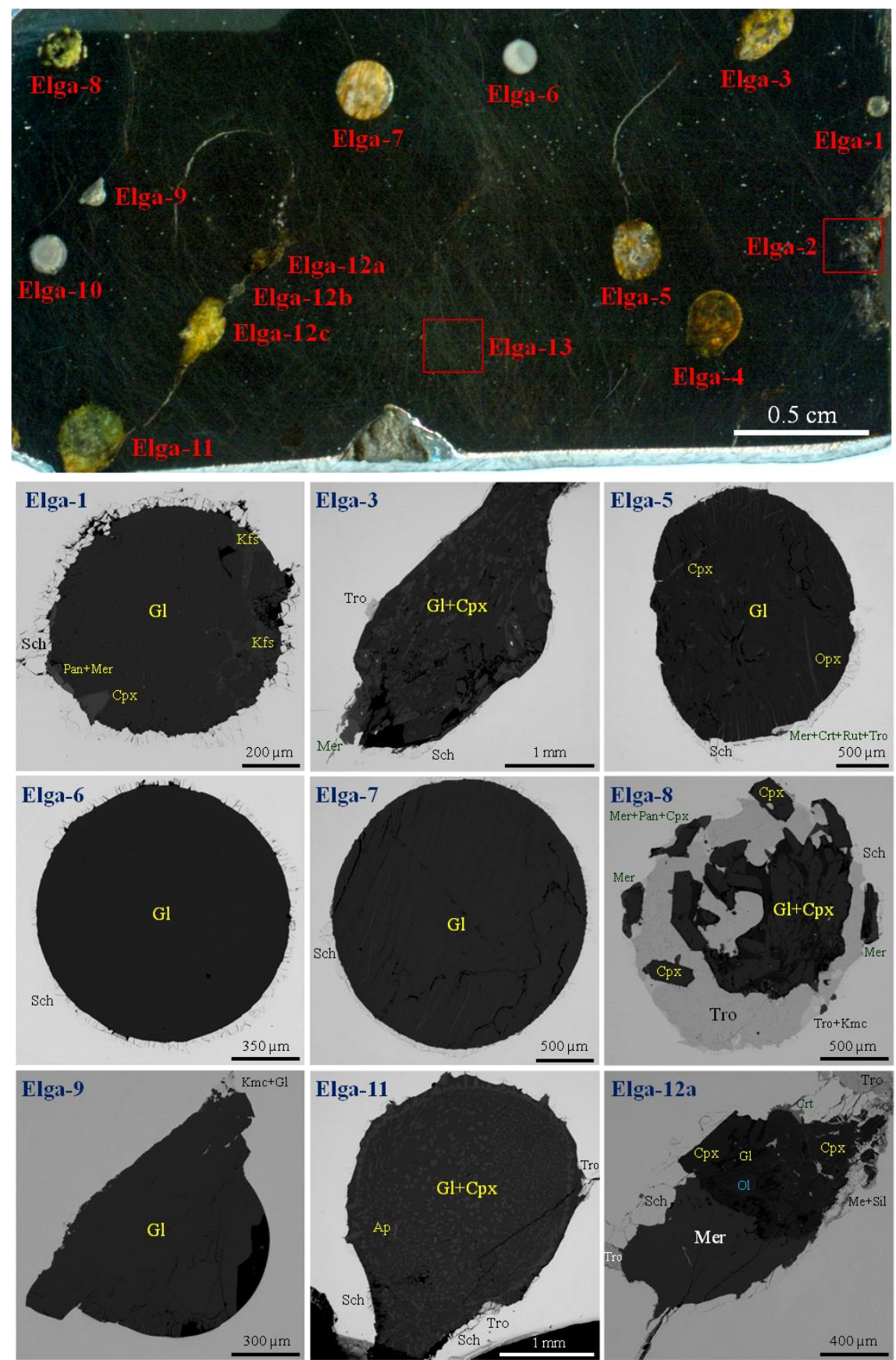

Figure 2. General view for the studied cut-off of the Elga meteorite and silicate inclusions in Fe-Ni-metal (BSE images). Elga-1-Elga-12c-individual silicate inclusions and areas. Symbols: Gl—siliceous glass; Sch—schreibersite; Tro-troilite; Cpx-diopsidic clinopyroxene; Kfs—potassic feldspar; Pan—panethite; Mer-merrillite; Opx—enstatite; Crt—chromite; Rut—rutile; Kmc-kamacite; Ap-fluorapatite; Ol—forsterite; $\mathrm{Me}+\mathrm{Sil}$-silicate globules in quenched Fe-Ni-P-S melt $(\mathrm{Kmc}+\mathrm{Sch}+$ Tro). Some details see also in Figures S1-S6 of Supplementary data.

The identification of all minerals was based on energy-dispersive spectra (EDS), back-scattered electron (BSE) images and elemental mapping (EDS system), using a TESCAN MIRA 3MLU scanning 
electron microscope equipped with an INCA Energy 450 XMax 80 microanalysis system (Oxford Instruments Ltd., Abingdon, UK) at the IGM, Novosibirsk, Russia. The EDS analyses of minerals were operated at an accelerating voltage of $20 \mathrm{kV}$ and a probe current of $1 \mathrm{nA}$ in high-vacuum mode and at an accumulation time of 20-40 s. The synthetic compounds, pure metals and minerals were used as reference standards for the elements: $\mathrm{SiO}_{2}(\mathrm{Si}$ and $\mathrm{O}), \mathrm{Al}_{2} \mathrm{O}_{3}(\mathrm{Al})$, diopside $(\mathrm{Mg}$ and $\mathrm{Ca}$ ), albite $(\mathrm{Na})$, orthoclase $(\mathrm{K}), \mathrm{Ca}_{2} \mathrm{P}_{2} \mathrm{O}_{7}(\mathrm{P}), \mathrm{BaF}_{2}(\mathrm{Ba}$ and $\mathrm{F}), \mathrm{Cr}_{2} \mathrm{O}_{3}(\mathrm{Cr}), \mathrm{CsRe}_{2} \mathrm{Cl}_{6}(\mathrm{Cl}), \mathrm{LaPO}_{4}(\mathrm{La})$, $\mathrm{CePO}_{4}(\mathrm{Ce}), \mathrm{SrF}_{2}(\mathrm{Sr})$, metallic Ti, Fe, Mn, $\mathrm{Zn}, \mathrm{Ni}, \mathrm{V}$ and $\mathrm{Cu}$. Matrix effects were corrected using the XPP algorithm, implemented in the software of the microanalysis system. Metallic Co served for quantitative optimization (normalization to probe current and energy calibration of the spectrometer). The overlapping of $\mathrm{TiK} \beta$ and $\mathrm{VK} \alpha$ was specially checked using the $\mathrm{TiO}_{2}$ and metallic $\mathrm{V}$ standards. The precision of the EDS analysis for major elements was better than $2 \%$ relative.

Electron microprobe analyses (EMPA) in wavelength-dispersive (WDS) mode were performed for all minerals of the Elga iron meteorite, using a JXA-8100 microprobe (Jeol Ltd., Tokyo, Japan) at the IGM. Grains (sizes $>5 \mu \mathrm{m}$ ) previously analyzed by EDS were selected for this purpose. The operating conditions were as follows: beam diameter of 1-2 $\mathrm{m}$, accelerating voltage of $20 \mathrm{kV}$, beam current of 10 (for silicates and phosphates) and $50 \mathrm{nA}$ (metals, sulfides and phosphides), and counting time of $10(5+5) \mathrm{s}$.

The following standards were used for microprobe sessions: oxide scheme-diopside $(\mathrm{Si}, \mathrm{Mg}$, $\mathrm{Ca})$, albite $(\mathrm{Na})$, orthoclase $(\mathrm{K}, \mathrm{Al})$, spessartite $(\mathrm{Fe}, \mathrm{Mn}), \mathrm{TiO}_{2}(\mathrm{Ti}), \mathrm{Cr}_{2} \mathrm{O}_{3}(\mathrm{Cr}), \mathrm{ZnFe}_{2} \mathrm{O}_{4}(\mathrm{Zn})$, $\mathrm{V}_{2} \mathrm{O}_{5}(\mathrm{~V})$, fluorapatite $(\mathrm{Ca}, \mathrm{P}, \mathrm{F})$, chlorapatite $(\mathrm{Cl})$ and synthetic Sr-Si-glass ( $\left.\mathrm{Sr}\right)$; metal-sulfide-phosphide scheme-natural/synthetic FeS or $\mathrm{FeS}_{2}(\mathrm{~S})$, Fe metal or FeS (Fe), Fe-Ni-Co alloy (Ni and Co), GaP (P), $\mathrm{Cr}_{2} \mathrm{O}_{3}(\mathrm{Cr}), \mathrm{ZnS}(\mathrm{Zn})$ and $\mathrm{CuFeS}_{2}(\mathrm{Cu})$. Correction for matrix effects was done using a PAP routine [23]. The precision of analysis for major elements was better than $2 \%$ relative. The detection limits for elements for oxide scheme were (in ppm): Si-458; Ti-207; Cr-208; V-1441; Al-196; Fe-176; Mn-161; $\mathrm{Zn-281;} \mathrm{Mg-424;} \mathrm{Ca-167;} \mathrm{Sr-1011;} \mathrm{Na-296;} \mathrm{K-117;} \mathrm{P-297;} \mathrm{F-530;} \mathrm{Cl-101.} \mathrm{The} \mathrm{overlappings} \mathrm{of}$ $\mathrm{TiK} \beta-\mathrm{VK} \alpha$ and $\mathrm{SiK} \alpha-\mathrm{SrL} \alpha$ were specially checked using the $\mathrm{TiO}_{2}, \mathrm{~V}_{2} \mathrm{O}_{5}$ and $\mathrm{SiO}_{2}$ standards.

The Raman spectra were recorded on a LabRAM HR 800 mm (HORIBA Scientific Ltd., Kyoto, Japan) spectrometer equipped with a 1024 pixel LN/CCD detector and coupled to an Olympus BX40 confocal microscope (objective $\times 100$ ) at the IGM. A semiconductor laser emitting at $514.5 \mathrm{~nm}$ with a nominal power output of $50 \mathrm{~mW}$ was used for excitation. In each case, 10-20 spectra were recorded for 10-20 s each at a hole diameter of 100-200 $\mu \mathrm{m}$ and integrated. Most spectra were recorded between 100 and $1200 \mathrm{~cm}^{-1}$, and some spectra were made for the $100-4000 \mathrm{~cm}^{-1}$ and $3000-4000 \mathrm{~cm}^{-1}$ region. The monochromator was calibrated using the $520.7 \mathrm{~cm}^{-1}$ Raman line of elemental Si.

The main results are presented in Figures 1-15 and Tables 1-9. Some data are given in Supplementary section (Figures S1-S14).

\section{Description of Studied Cut-off from the Elga Meteorite}

The polished cut-off $(35 \times 18 \times 2 \mathrm{~mm}$, Figure 2$)$ was used for detailed studies by optical and scanning electron microscopy, EMPA and Raman spectroscopy. The sample contains 12 silicate inclusions of different composition (Elga-1, Elga-3-Elga-12a, Elga-12c) as well as areas with impact melting (Elga-12b, Elga-13) and zone of surface oxidation of the meteorite (Elga-2). The phase composition of silicate inclusions varies from glassy to partially and completely crystallized (Figure 2), which corresponds to previous description of the inclusions in the Elga meteorite $[5,8,9,11-13,15]$. Some inclusions indicate the abundance in troilite (Elga-8, Figure 2 and Figure S6), even up to the appearance of individual sulfide nodules. Milky white inclusions are dominant in glass, but, in anyway, micron-sized microlites of silicates are fixed in them under high magnification (Figures S4 and S5). Areas of local impact melting are confined to cracks in metal (Figure 2, Figure 3 and Figure S1) and visible in the inclusions. Sometimes the cracks joint the neighboring silicate inclusions (Figure 2, line Elga-11-Elga-12). In general, the texture and phase composition of such impact assemblages are similar to those described previously in the Elga meteorite $[8,10,14,16,19,20]$. In the studied sample, 
the impact associations in Fe-Ni-metal are mainly represented by quenched structures of kamacite + schreibersite + troilite, sometimes with silicate or silicate-phosphate blebs (Figure 3 and Figure S1).

The zone of surface terrestrial oxidation is up to 1-2 $\mathrm{mm}$ and represented by goethite (and other Fe-rich oxyhydroxides and hydroxides), hematite, siderite and hydrated Na-rich Fe-phosphates (maybe close to vivianite) (Figure S2). In addition, secondary phases (chlorite, serpentine, goethite and hydrated Na-rich Fe-phosphate) also occur within silicate inclusions (Figure 6, Figure 8, Figure 9, Figures S5 and S7-S9) and in cracks in Fe-Ni-metal.
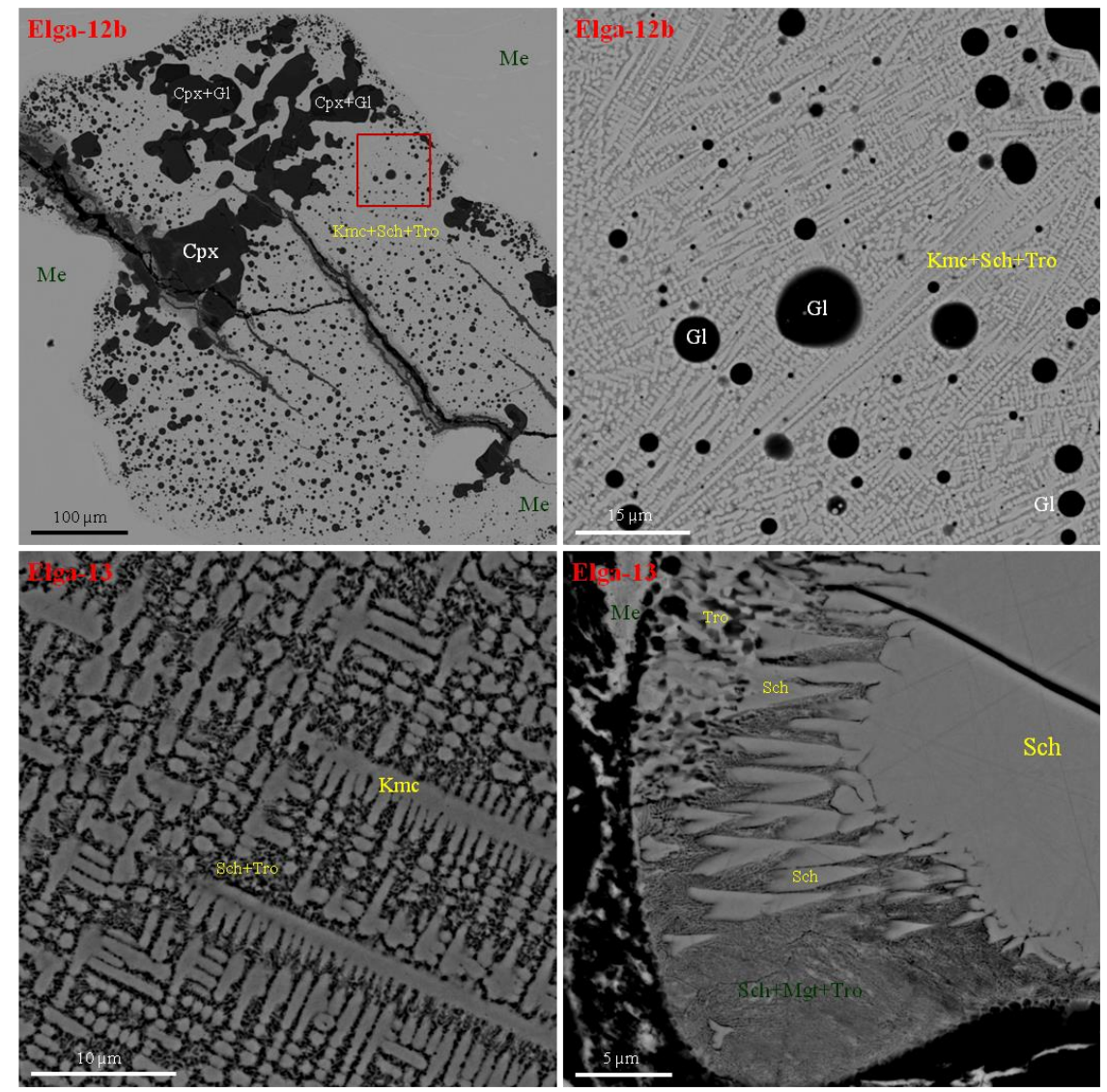

Figure 3. Areas of local impact melting and further quenching in the Elga meteorite (BSE images). Gl—silicate glass; Sch—schreibersite; Tro-troilite; Cpx-diopsidic clinopyroxene; Kmc-kamacite; Mgt—magnetite; Me-kamacite \pm taenite.

\section{Inclusion with Silicate-Natrophosphate Immisciblity (Elga-4)}

Among all silicate inclusions found in the studied Elga sample, only one inclusion (Elga-4) drastically differs in mineralogy and petrography (Figures 4 and 5). In general, it is a new type of silicate inclusions for the Elga meteorite, which was discovered in recently studied samples, and at present day, only few inclusions have been found [12,13,17]. Litasov and Podgornykh [13] described them as type 3- "silicate/phosphate inclusions with liquid immiscibility". The most remarkable features of such inclusions are the occurrence of natrophosphate globule (isolation) and exotic mineralogy of both silicates and phosphates, enriched in $\mathrm{Na}$.

\subsection{General Description of the Immiscible Inclusion}

The studied silicate inclusion (Elga-4) is oval, $3 \mathrm{~mm}$ in size and brown in color. It has a specific texture due to pronounced silicate $(\approx 90 \mathrm{vol} . \%)$-natrophosphate $(\approx 10 \mathrm{vol} . \%)$ liquid immiscibility (Figure 4). Schreibersite and troilite form rim zones around the silicate inclusion: their distribution is 
well fixed into the characteristic radiations of P, S, Fe and Ni (Figure 5). It should be noted that host kamacite around the inclusion is virtually free in taenite and "plessite" ( $\approx 100 \mu \mathrm{m}$ zone). Compositions of schreibersite, troilite and host kamacite are given in Table 2. The natrophosphate part mainly forms a meniscus-like isolation of $\mathrm{Na}-\mathrm{Ca}-\mathrm{Mg}$-Fe phosphates with minor $\mathrm{Na-Ti-rich} \mathrm{pyroxene,} \mathrm{although}$ individual grains of phosphates sporadically occur in the periphery of the silicate part of the inclusion in direct contact with schreibersite or troilite (Figures 6 and 8). They decorate an individual inner zone like troilite and schreibersite ones; this is clearly visible in the characteristic radiations of $\mathrm{P}$ and $\mathrm{Ca}$ (Figure 5). Silicate part of the inclusion contains mainly alkali feldspars, quartz, glass and Na-Ti-Cr-rich silicates (amphibole, clinopyroxene, aenigmatite). In contrast with other inclusion types in the Elga meteorite, this inclusion drastically differs in high abundance of alkalis (namely, Na) and Ti.

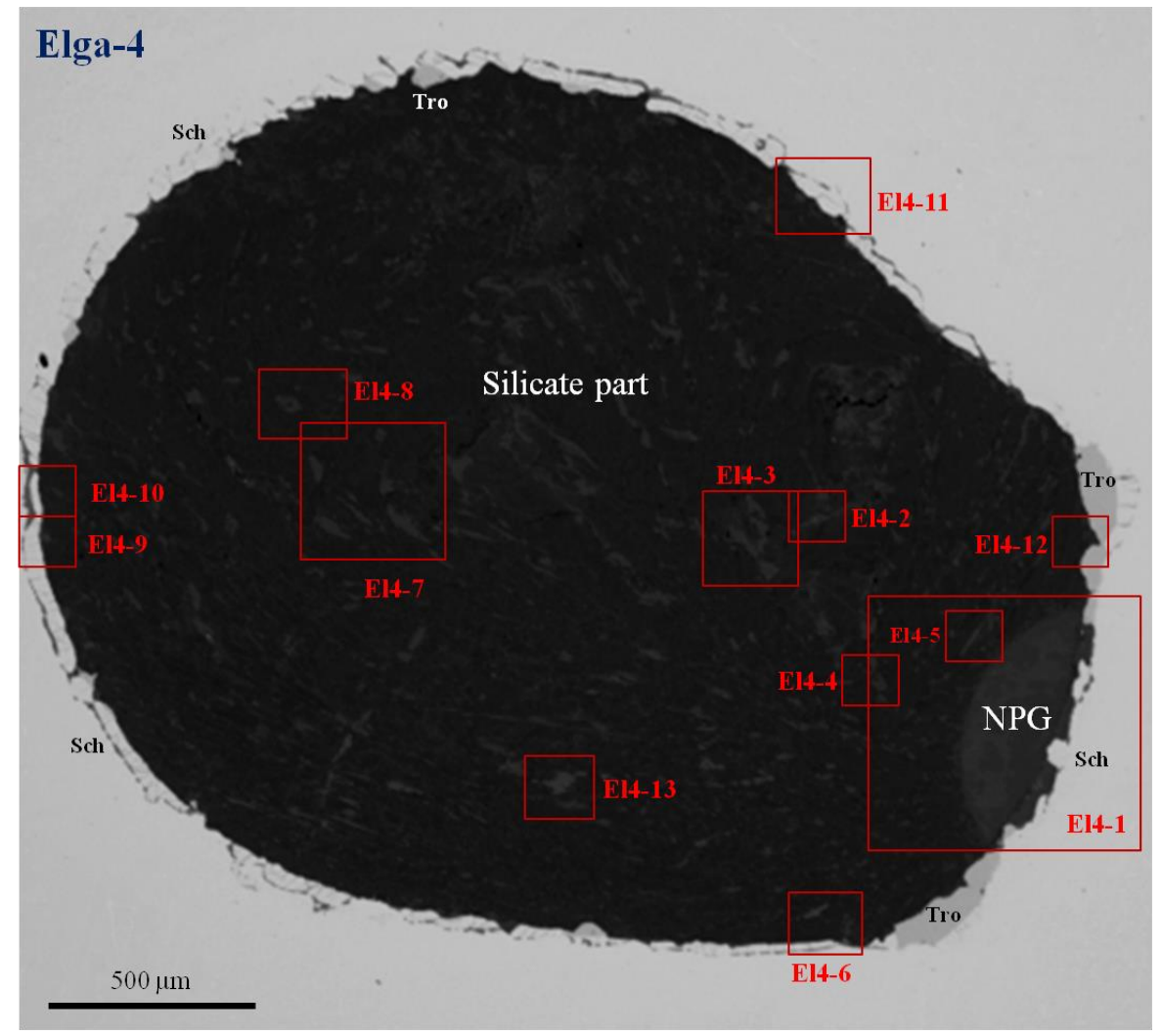

Figure 4. Silicate inclusion (Elga-4) with the silicate-natrophosphate immiscibility (BSE image). Symbols: NPG—natrophosphate globule; Sch—schreibersite; Tro-troilite. El4-1-El4-13-areas, which are shown mineral associations within the inclusion. See also Figures 5-9 and Figures S7-S12 in Supplementary data.

Table 2. Chemical composition (WDS, wt.\%) of kamacite, schreibersite and troilite from rim around the Elga-4 immiscible inclusion in the Elga meteorite.

\begin{tabular}{lccc}
\hline \multirow{2}{*}{ Mineral } & Kamacite & Schreibersite & Troilite \\
\cline { 2 - 4 } & $\mathbf{N}=\mathbf{5}$ & $\mathbf{N}=\mathbf{6}$ & $\mathbf{N}=\mathbf{3}$ \\
\hline $\mathrm{P}$ & n.d. & 15.20 & n.d. \\
$\mathrm{S}$ & n.d. & n.d. & 36.64 \\
$\mathrm{Fe}$ & 93.08 & 60.10 & 63.51 \\
$\mathrm{Co}$ & 0.45 & 0.13 & n.d. \\
$\mathrm{Ni}$ & 6.44 & 24.69 & n.d. \\
Sum & 99.97 & 100.11 & 100.15 \\
\hline
\end{tabular}

n.d.- not detected. 

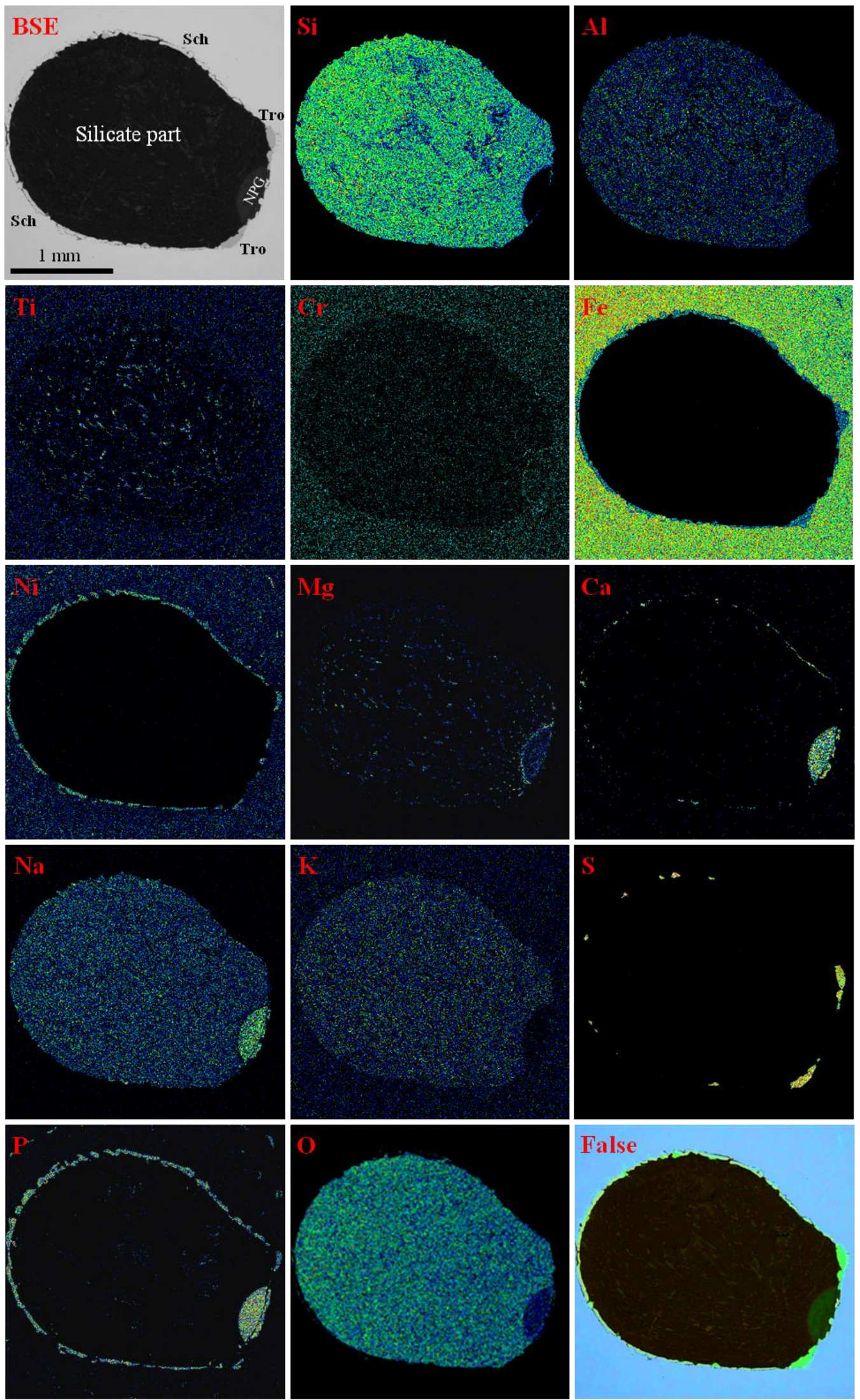

Figure 5. BSE image and elemental maps for the silicate inclusion (Elga-4) with the silicatenatrophosphate immiscibility. Symbols: NPG—natrophosphate globule; Sch—schreibersite; Tro—troilite. 


\subsection{Mineralogy of Silicate Part}

The silicate part of the studied immiscible inclusion mainly contains fine-grained (sometimes symplectitic) quartz-feldspars aggregate (former glass) and mafic silicates; other minerals (chromite, pentlandite and altered phases) are minor or accessory (Figure 6 and Figures S7-S9). Ontogeny (hollow and skeletal crystals) and relationships of minerals indicate about quenching and rapid crystallization within the inclusion. The relations of feldspars ("layered" grains) assume solid decay of initially homogenous K-Na-feldspar into albite and K-feldspar with temperature decreasing (Figure 6 and Figure S9). Silicate glass is present in small amounts and locally preserved in the outer zone of the inclusion (Figure 8). Mafic silicates are very specific in composition: dominant phase is an obertiite-subgroup oxyamphibole; minor phases are low-Ca-pyroxene (orthopyroxene), aenigmatite-subgroup mineral (sapphirine supergroup) and the diopside-kosmochlor- $\mathrm{Na}(\mathrm{Mg}, \mathrm{Fe})_{0.5} \mathrm{Ti}_{0.5} \mathrm{Si}_{2} \mathrm{O}_{6}$ clinopyroxene series.
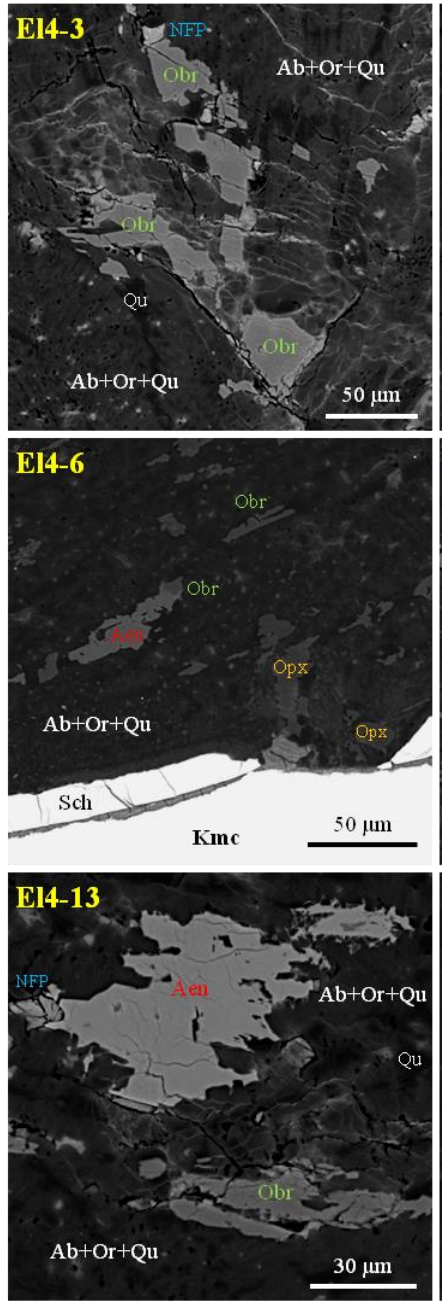
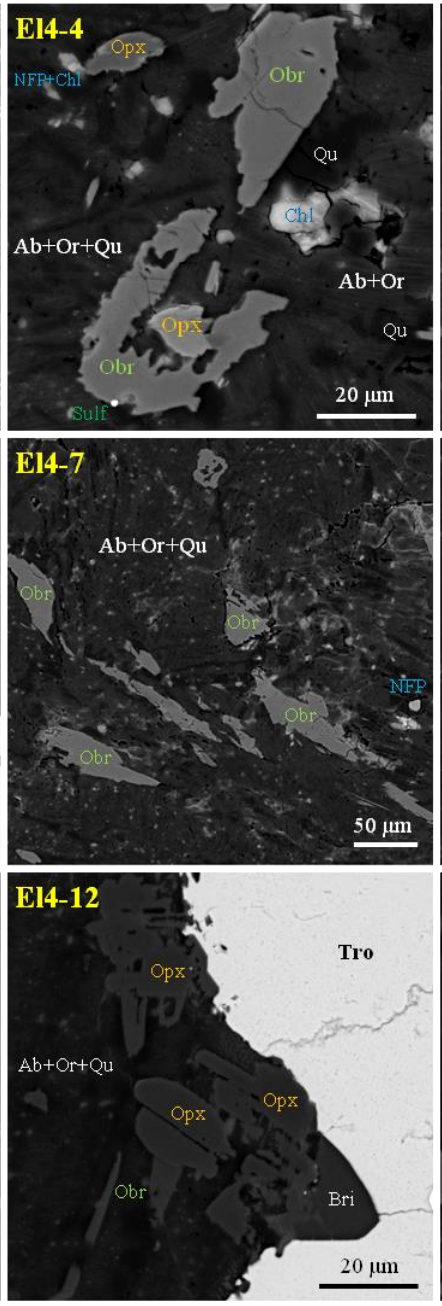
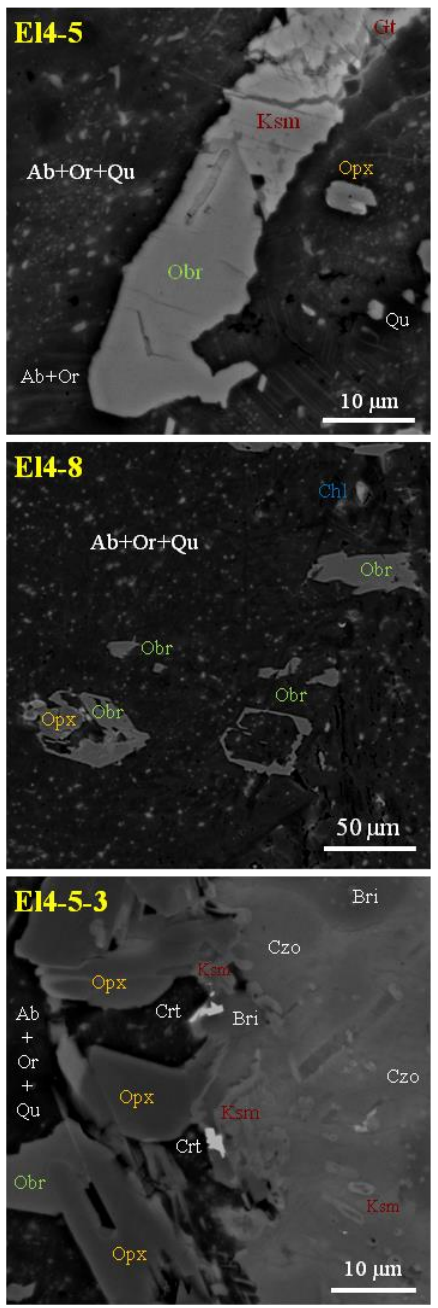

Figure 6. Relationships of minerals in silicate part of the immiscible inclusion (Elga-4), BSE images. Position of the areas sees Figure 4. Symbols: Ab-albite; Or-K-feldspar; Qu-quartz; Obr-mineral of the obertiite-subgroup; NFP-hydrated Na-Fe-phosphate (vivianite ?); Chl_Fe-rich chlorite; Sulf-sulphide (pentlandite ?); Opx—enstatite; Gt—goethite; Ksm-clinopyroxene of the diopside $\mathrm{Ca}(\mathrm{Mg}, \mathrm{Fe}) \mathrm{Si}_{2} \mathrm{O}_{6}-$ kosmochlor $\mathrm{NaCrSi}_{2} \mathrm{O}_{6}-\mathrm{Na}(\mathrm{Mg}, \mathrm{Fe})_{0.5} \mathrm{Ti}_{0.5} \mathrm{Si}_{2} \mathrm{O}_{6}$ series; Aen-mineral of the aenigmatite subgroup; Crt—chromite; Bri—brianite; Czo—czochralskiite; Sch—schreibersite; Tro—troilite.

Ti-rich oxyamphibole is omnipresent in this part, whereas pyroxenes are commonly confined to the boundary between silicate and natrophosphate parts. In general, orthopyroxene decorates the silicate-natrophosphate contact (Figures 5 and 7) and the growth of these crystals was directed from 
the contact into the silicate part. This is clearly visible in the characteristic radiation of $\mathrm{Mg}$ (Figure 5, Figure 7 and Figure S12).
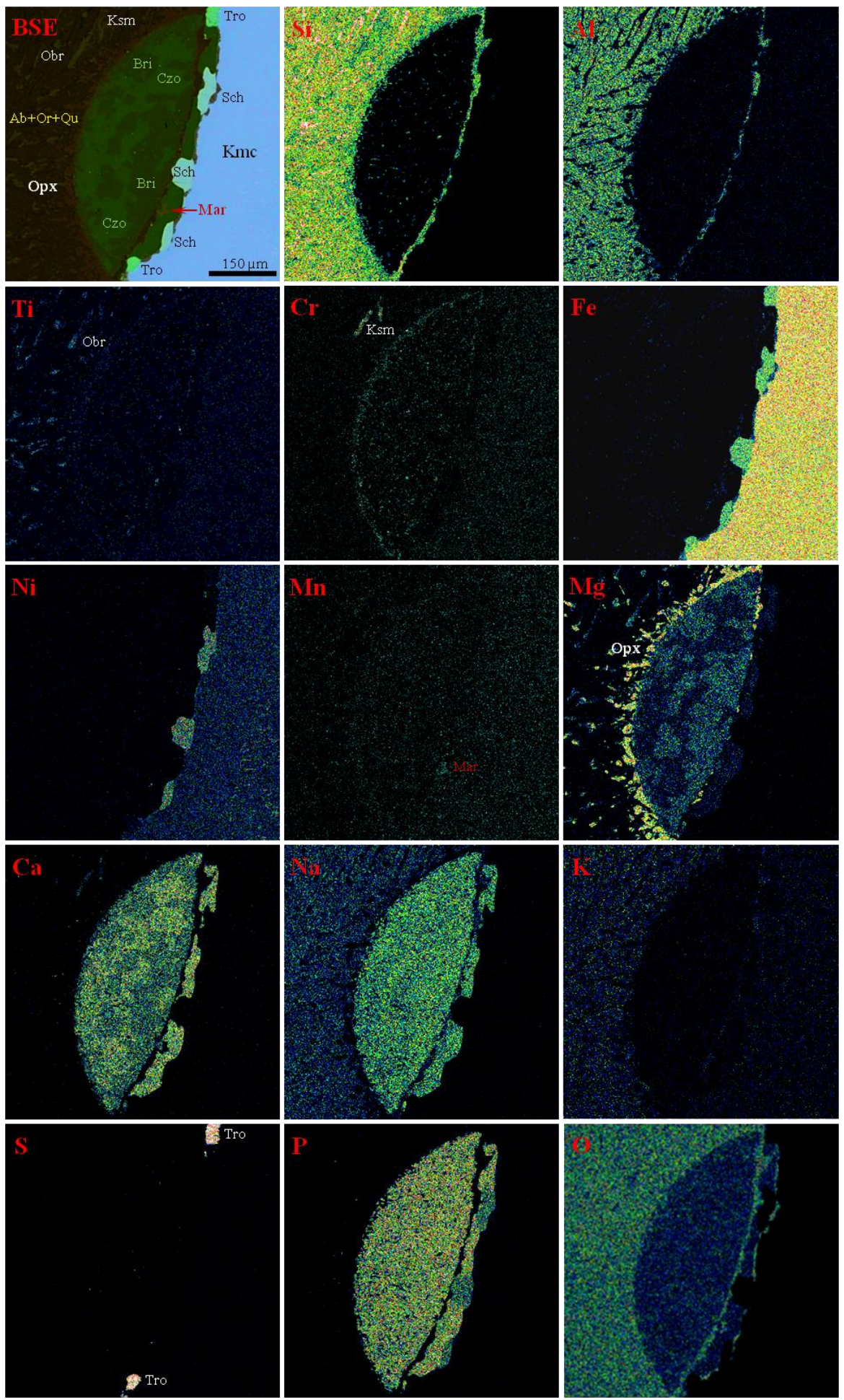

Figure 7. BSE image and elemental maps for natrophosphate globule of the Elga- 4 immiscible inclusion. Position of the area sees Figure 4. Symbols: Ab—albite; Or-K-feldspar; Qu-quartz; Obr-mineral of the obertiite subgroup; Opx-enstatite; Ksm-clinopyroxene of the diopside-kosmochlor $\mathrm{Na}(\mathrm{Mg}, \mathrm{Fe})_{0.5} \mathrm{Ti}_{0.5} \mathrm{Si}_{2} \mathrm{O}_{6}$ series; Bri-brianite; $\mathrm{Czo}$-czochralskiite; Mar-marićite; Sch—schreibersite; Tro-troilite; Kmc-kamacite. 
The occurrence of chromite is also related to this contact (Figure 6, Figure 9 and Figure S10). Previously this mineral was chemically labelled as eskolaite due to very small sizes [12,17]. The relations of mafic silicates indicate that orthopyroxene is an earlier mineral, whereas oxyamphibole is a later phase (Figure 6). The appearance of Fe-rich chlorite, goethite and hydrated phosphate (close to vivianite $\mathrm{Fe}^{2+}{ }_{3}\left(\mathrm{PO}_{4}\right)_{2} \cdot 8 \mathrm{H}_{2} \mathrm{O}$ and with $\left.\mathrm{Na}_{2} \mathrm{O}-2.3-3.3 \mathrm{wt} . \%\right)$ is attributed to alteration process within the inclusion (Figure 6, Figure 8 and Figures S8 and S9). The hydrated phosphate seems to be alteration product of former anhydrous Na-Fe-phosphate.

\subsection{Mineralogy of Natrophosphate Part}

Natrophosphate part forming meniscus-like isolation (globule) consists of aggregate of three orthophosphates (brianite, czochralskiite and marićite) and minor complex Na-Cr-Ti-clinopyroxene, pentlandite, rarely taenite (Figure 4, Figure 5, Figure 6, Figure 7, Figure 9 and Figures S10-S12). The individual grains of anhydrous phosphates occurring beyond of the globule (Figure 8) are represented by brianite and czochralskiite. Like orthopyroxene in the silicate part complex clinopyroxene also forms a discrete zone, which decorates the contact into the natrophosphate part and well-fixed in the characteristic radiation of $\mathrm{Cr}$ (Figure 7). The relationships of minerals within the natrophosphate globule indicate that clinopyroxene is earlier phase than phosphates, and pentlandite and taenite form blebs in phosphates. In addition, the silicate vein cross-cuts the natrophosphate globule (Figure 7, Figure 9 and Figure S11), evidencing about earlier crystallization of phosphatic melt rather than silicate ones.

\subsection{Chemistry of Minerals in the Elga-4 Immiscible Inclusion}

\subsubsection{Feldspars, Quartz and Siliceous Glass}

As mentioned above, the fine-grained quartz-feldspars aggregate is the main component of the studied inclusion and is a result of complete crystallization of residual silicate melt or quenched product after siliceous glass. In general, compositions of feldspars very strongly vary due to the alternation of the albite and K-feldspar "layers" in most grains. Homogeneous grains of albite or K-feldspar occur rarely (Figure S9). Maximal compositions correspond to $\mathrm{Ab}_{92.4} \mathrm{Or}_{7.5} \mathrm{An}_{0.1}$ for albite and $\mathrm{Ab}_{27.8} \mathrm{Or}_{71.3} \mathrm{An}_{0.9}$ for K-feldspar, whereas intermediate compositions presented in Table 3 seem to be result of trapping of both minerals in "layered" grains during the WDS-EDS analyses. Large grains of quartz (supported by Raman spectroscopy, see below) contain mainly FeO (up to 0.5 wt.\%) as admixture. Siliceous glass is virtually free in $\mathrm{CaO}$ and strongly varies in the major components depending on the degree of total crystallization (in wt.\%): $\mathrm{SiO}_{2}$ 68.1-79.1; $\mathrm{Al}_{2} \mathrm{O}_{3}$ 10.6-16.9; FeO 1.1-3.4; $\mathrm{MgO} 0.2-0.6$; $\mathrm{Na}_{2} \mathrm{O}$ 5.8-8.7; $\mathrm{K}_{2} \mathrm{O}$ 2.3-3.9. In general, such variations are common for the Elga glass-containing inclusions [5,8,9,13,15], which are virtually free in water (0.06-0.12 wt.\%, SIMS data) [9].
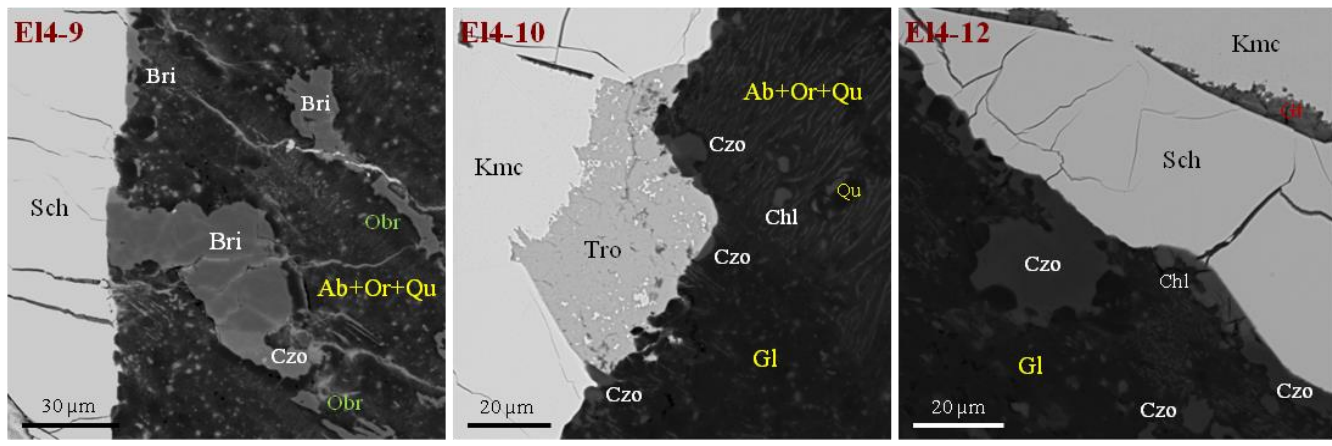

Figure 8. BSE images for Na-Ca-Mg-phosphates in the eldge of the Elga-4 immiscible inclusion. Position of the areas sees Figure 4. Symbols: Ab-albite; Or-K-feldspar; Qu-quartz; Gl—siliceous glass; Obr-mineral of the obertiite subgroup; Bri-brianite; Czo-czochralskiite; Sch—schreibersite; Gt-goethite; Chl—Fe-rich chlorite; Tro—troilite; Kmc-kamacite. 

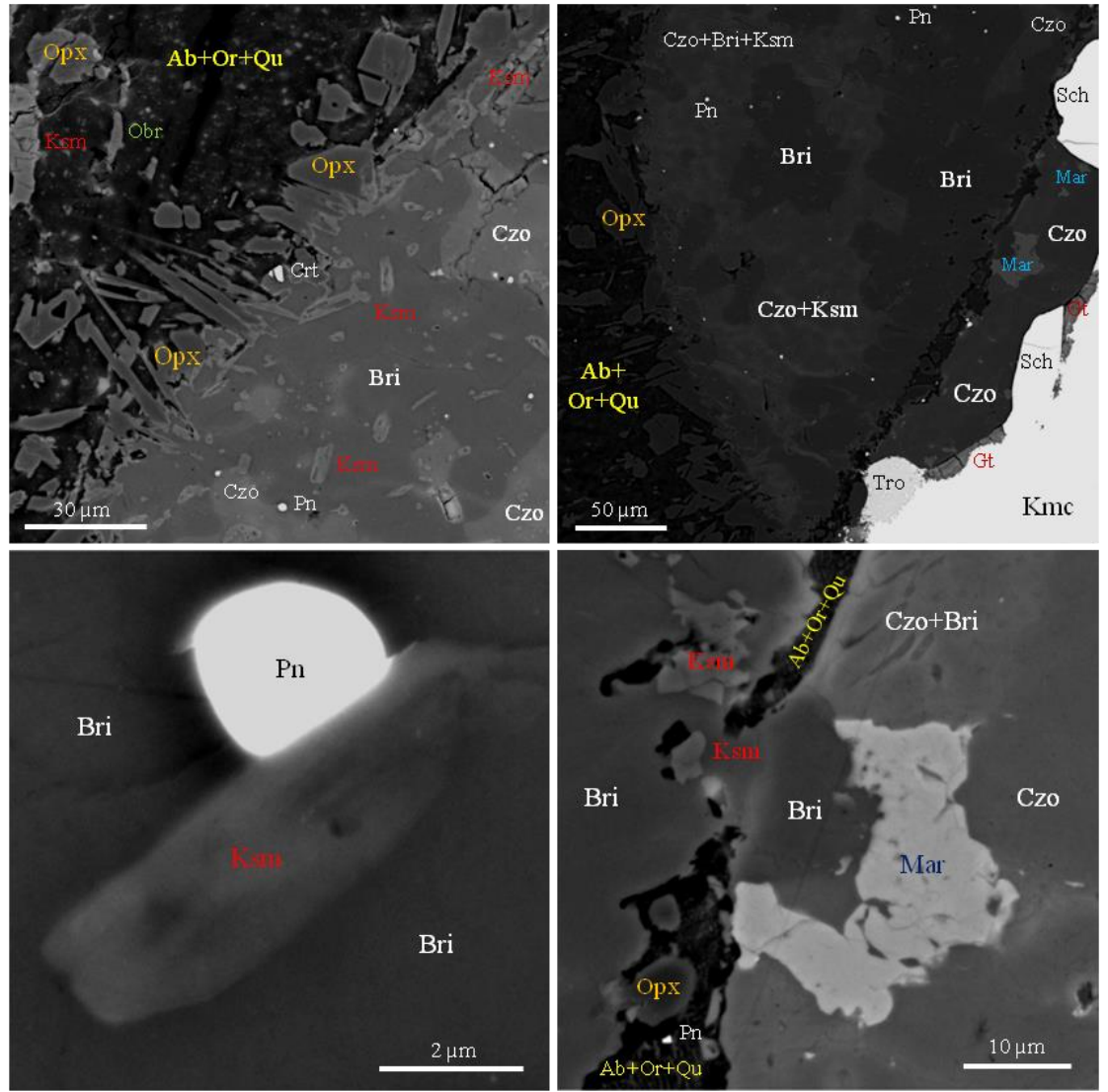

Figure 9. Relationships of minerals on the silicate-natrophosphate contact and in the natrophosphate globule of the Elga-4 immiscible inclusion (BSE images, see Figures 4, 6 and 7). Symbols: $\mathrm{Ab}$-albite; Or-K-feldspar; Qu-quartz; Obr-mineral of the obertiite subgroup; Opx—enstatite; Ksm-clinopyroxene of the diopside-kosmochlor- $\mathrm{Na}\left(\mathrm{Mg}, \mathrm{Fe}_{0.5} \mathrm{Ti}_{0.5} \mathrm{Si}_{2} \mathrm{O}_{6}\right.$ series; Crt-chromite; Bri-brianite; Czo—czochralskiite; Mar-marićite; Sch—schreibersite; Tro-troilite; Kmc-kamacite; Gt—goethite; Pn—pentlandite. Some details see also Figures S10-S12 in Supplementary data.

Table 3. Chemical composition (WDS, wt.\%) of feldspars, quartz and siliceous glass from the Elga-4 immiscible inclusion in the Elga meteorite.

\begin{tabular}{ccccccccc}
\hline & $\mathbf{1}$ & $\mathbf{2}$ & $\mathbf{3}$ & $\mathbf{4}$ & $\mathbf{5}$ & $\mathbf{6}$ & $\mathbf{7}$ & $\mathbf{8}$ \\
\hline Phase & & & Albite & & & K-feldspar & Quartz & Glass \\
\hline Position & $\mathbf{E l 4 - 2}$ & $\mathbf{E l 4 - 5}$ & $\mathbf{E l 4 - 3}$ & $\mathbf{E l 4 - 2}$ & $\mathbf{E l 4 - 2}$ & $\mathbf{E l 4 - 2}$ & $\mathbf{E l 4}$ & $\mathbf{E l 4}$ \\
\hline Area & $\mathbf{N = 2}$ & $\mathbf{N = 1}$ & $\mathbf{N = 1}$ & $\mathbf{N = 4}$ & $\mathbf{N = 4}$ & $\mathbf{N = 2}$ & $\mathbf{N = \mathbf { 8 }}$ & $\mathbf{N}=\mathbf{6}$ \\
\hline $\mathrm{SiO}_{2}$ & 69.80 & 68.85 & 69.43 & 69.59 & 67.04 & 66.69 & 99.44 & 72.18 \\
$\mathrm{Al}_{2} \mathrm{O}_{3}$ & 16.50 & 16.03 & 16.19 & 16.18 & 15.75 & 15.41 & n.d. & 14.40 \\
$\mathrm{FeO}$ & 0.87 & 1.78 & 0.91 & 1.27 & 1.56 & 2.41 & 0.47 & 2.05 \\
$\mathrm{MnO}$ & 0.04 & n.d. & n.d. & n.d. & n.d. & 0.04 & n.d. & n.d. \\
$\mathrm{MgO}$ & 0.68 & 0.29 & 0.85 & 0.80 & 0.81 & 0.83 & n.d. & 0.36 \\
$\mathrm{CaO}$ & 0.01 & n.d. & n.d. & n.d. & n.d. & 0.18 & n.d. & n.d. \\
$\mathrm{Na} 2 \mathrm{O}$ & 10.53 & 11.26 & 9.09 & 8.66 & 5.67 & 2.95 & n.d. & 7.55 \\
$\mathrm{~K}_{2} \mathrm{O}$ & 1.29 & 1.73 & 3.87 & 3.30 & 8.52 & 11.50 & n.d. & 3.09 \\
$\mathrm{Sum}$ & 99.73 & 99.94 & 100.34 & 99.81 & 99.34 & 100.01 & 99.91 & 99.62 \\
\hline Albite & 92.46 & 90.82 & 78.12 & 79.96 & 50.27 & 27.81 & & \\
Orthoclase & 7.47 & 9.18 & 21.88 & 20.04 & 49.73 & 71.27 & & \\
Anorthite & 0.07 & 0.00 & 0.00 & 0.00 & 0.00 & 0.92 & & \\
Quartz & & & & & & & 100.00 & \\
\hline
\end{tabular}

$\mathrm{TiO}_{2}, \mathrm{Cr}_{2} \mathrm{O}_{3}, \mathrm{P}_{2} \mathrm{O}_{5}, \mathrm{~F}$ and $\mathrm{Cl}$ are below detection limits (<0.005 wt.\%); n.d.-not detected. 1-2-individual grains of albite; 3-5-feldspar zones from "layered" grains; 6-individual grain of K-feldspar. 


\subsubsection{Mineral of the Obertiite Subgroup (Amphibole Supergroup)}

$\mathrm{Na}$-Ti-rich oxyamphibole is dominant silicate in the studied inclusion. It should be mentioned that minerals of the amphibole supergroup rather rarely occur in meteorites (see review in [24]). Moreover, Ti-rich oxyamphiboles and Na-rich amphiboles are exceptional rarities in meteorites: the kaersutite subgroup minerals are known in the Martian samples [25-30] and magnesio-arfvedsonite was described in the Kaidun meteorite [31]. The chemical compositions for amphibole in the Elga meteorite are given in Table 4. Its averaged formula $(\mathrm{N}=54)$ is $\left(\mathrm{Na}_{0.85} \mathrm{~K}_{0.13}\right)\left(\mathrm{Na}_{1.67} \mathrm{Ca}_{0.33}\right)$ $\left(\mathrm{Mg}_{2.73} \mathrm{Fe}^{2+}{ }_{0.70} \mathrm{Fe}^{3+}{ }_{0.21} \mathrm{Mn}_{0.05} \mathrm{Cr}_{0.03} \mathrm{Ti}_{1.28}\right)\left(\mathrm{Si}_{7.77} \mathrm{Fe}^{3+}{ }_{0.16} \mathrm{Al}_{0.07} \mathrm{O}_{22}\right)\left(\mathrm{O}_{1.87} \mathrm{~F}_{0.13}\right)$.

Table 4. Chemical composition (WDS, wt.\%) of the obertiite-subgroup mineral from the Elga-4 immiscible inclusion, Elga meteorite.

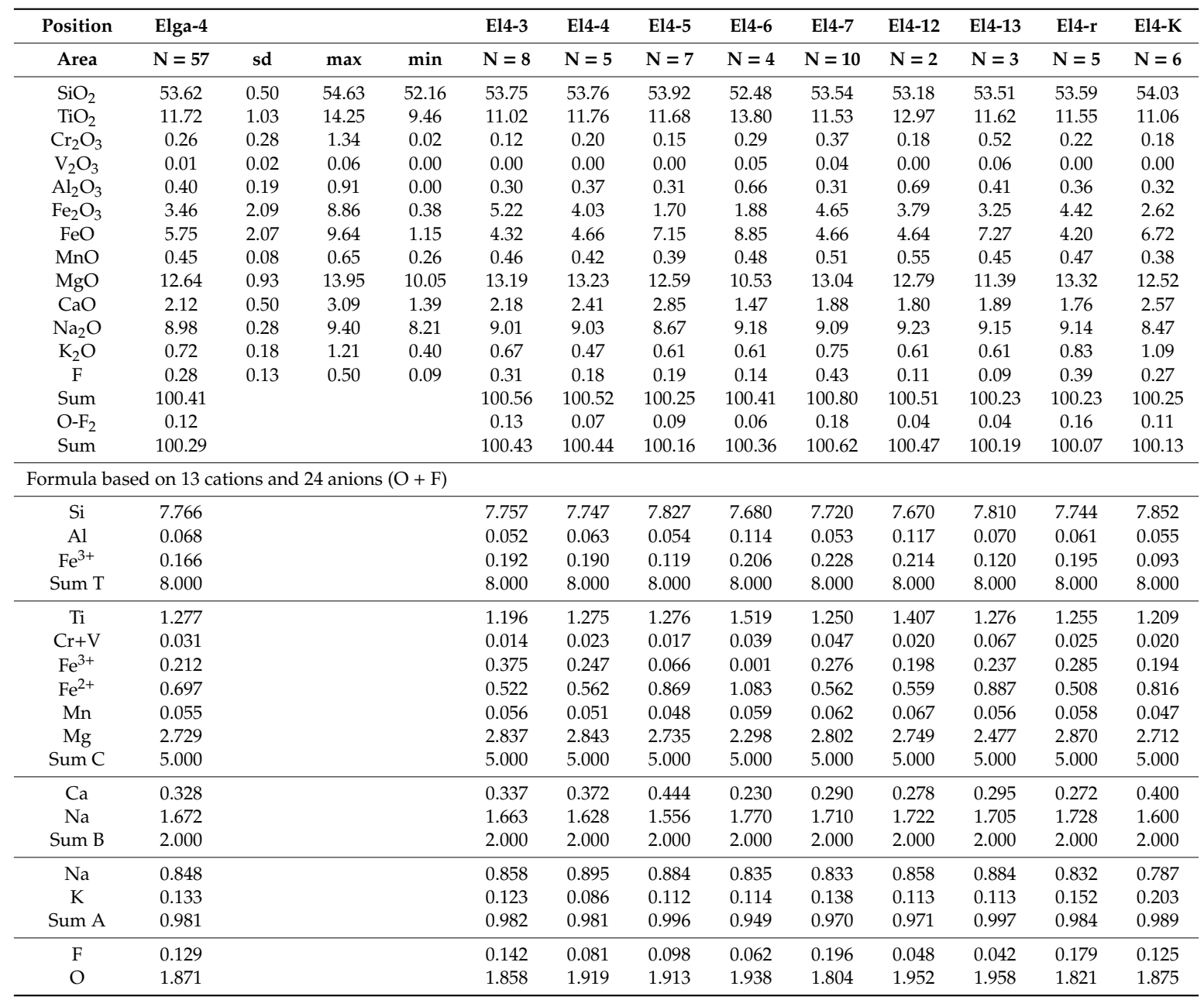

$\mathrm{P}_{2} \mathrm{O}_{5}, \mathrm{Cl}$ and $\mathrm{ZnO}$ are below detection limits ( $<0.005 \mathrm{wt}$. \%). Formulas are calculated on 13 cations $(8$ tetrahedra + 5 octahedra) and 24 anions $(\mathrm{O}+\mathrm{F})$. FeO and $\mathrm{Fe}_{2} \mathrm{O}_{3}$ are calculated on charge balance at assumption of water-free composition. Elga-4-mean of all compositions; El4-6-mean of high-Ti compositions $\left(\mathrm{TiO}_{2}>13.5\right.$ wt.\%); El4-K-mean of K-rich compositions $\left(\mathrm{K}_{2} \mathrm{O}>1.0 \mathrm{wt} . \%\right)$. N, sd, min, max-average, standard deviation, minimal and maximal values. The position of some grains is in Figure 6.

This amphibole belongs to the obertiite root name (subgroup) of the $\mathrm{w}(\mathrm{O})$-dominant amphibole group according to the recent nomenclature for the amphibole supergroup [32,33]. In general, it is approximately close to ferri-obertiite $\mathrm{NaNa}_{2} \mathrm{Mg}_{3} \mathrm{Fe}^{3+} \mathrm{Ti}_{(}\left(\mathrm{Si}_{8} \mathrm{O}_{22}\right) \mathrm{O}_{2}$. However, the Elga mineral drastically differs from terrestrial oxyamphiboles of the obertiite subgroup [34-38] in its very high $\mathrm{Ti}$ content (1.03-1.57 apfu, Table 4 and Figure 10). The core-to-rim chemical deviations within individual grains of the Elga obertiite mineral are negligible. Nevertheless, the compositional variations for all grains are very essential (Table 4 and Figure 10). In general, the mineral shows a pronounced positive 
correlation between Ti and $\mathrm{Fe}^{2+}$ and negative ones for Ti with $\mathrm{Mg}$, $\mathrm{Fe}^{3+}$ and Si. Other Ti correlations (with $\mathrm{Al},(\mathrm{Na}+\mathrm{K})$ and $\mathrm{Ca}$ ) are weaker (Figure 10). Thus, the main isomorphic schemes of the Elga oxyamphibole are $2 \mathrm{Fe}^{3+} \leftrightarrow \mathrm{Ti}^{4+}+\mathrm{Fe}^{2+}$ and $2 \mathrm{Mg}^{2+}+2 \mathrm{Fe}^{3+} \leftrightarrow \mathrm{Ti}^{4+}+3 \mathrm{Fe}^{2+}$, which cover variations from

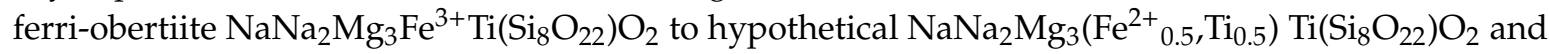
$\mathrm{NaNa}_{2} \mathrm{Fe}^{2+}{ }_{3}\left(\mathrm{Fe}^{2+}{ }_{0.5}, \mathrm{Ti}_{0.5}\right) \mathrm{Ti}\left(\mathrm{Si}_{8} \mathrm{O}_{22}\right) \mathrm{O}_{2}$ end-members (Figure 11). Other isomorphic schemes like $\mathrm{Ca}^{2+}$ $+2 \mathrm{Fe}^{3+}+\mathrm{Si}^{4+} \leftrightarrow \mathrm{Na}^{+}+2 \mathrm{Ti}^{4+}+\mathrm{Al}^{3+}$ are negligible. In addition, the Elga mineral also contains moderate concentrations of $\mathrm{K}_{2} \mathrm{O}$ (up to $1.2 \mathrm{wt} . \%, 0.23 \mathrm{apfu}$ ) and $\mathrm{F}$ (up to $0.5 \mathrm{wt} . \%, 0.23 \mathrm{apfu}$ ). The Raman spectra did not show any evident bands in the $3000-4000 \mathrm{~cm}^{-1}$ region (vibrations for OH-group, see below).

As shown in Figure 11, the part of the Elga amphibole compositions is dominant in the hypothetical $\mathrm{NaNa}_{2} \mathrm{Mg}_{3}\left(\mathrm{Fe}^{2+}{ }_{0.5}, \mathrm{Ti}_{0.5}\right) \mathrm{Ti}\left(\mathrm{Si}_{8} \mathrm{O}_{22}\right) \mathrm{O}_{2}$ end-member $(>50$ mol.\%). It seems to give support for declaration of a potentially new mineral species using the $50 \%$ rule of IMA. However, it needs further detailed studies of the crystal structure and chemical composition. It is known that in addition to the octahedral environments, Ti may occupy the tetrahedral site in the crystal structure of some amphiboles [34,39]. Moreover, this mineral should be carefully checked up on the real concentrations of $\mathrm{TiO}_{2}$ and $\mathrm{Ti}_{2} \mathrm{O}_{3}, \mathrm{FeO}$ and $\mathrm{Fe}_{2} \mathrm{O}_{3}, \mathrm{Li}_{2} \mathrm{O}, \mathrm{F}$ and $\mathrm{H}_{2} \mathrm{O}$. All these components may essentially influence on the formula calculation.
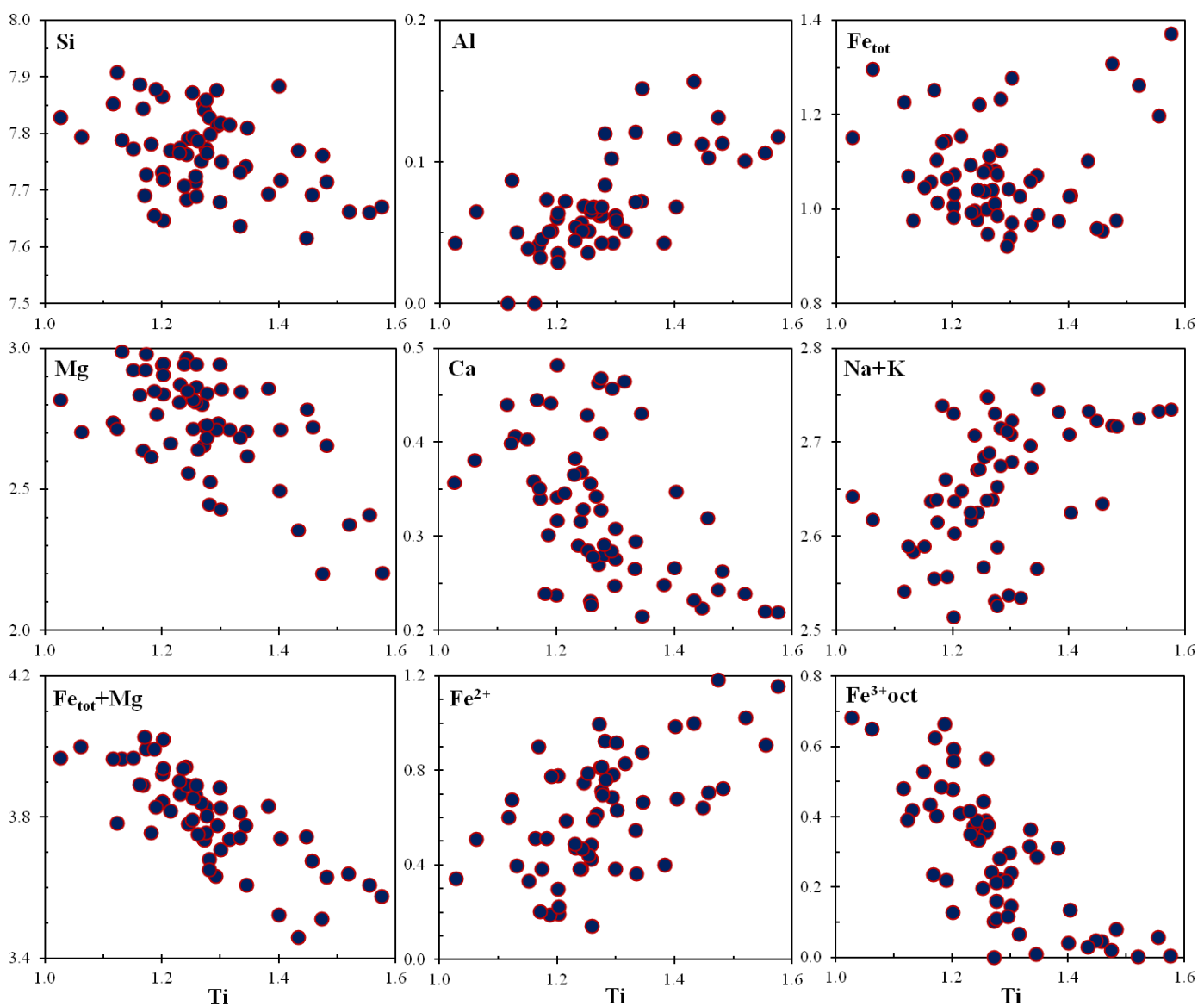

Figure 10. Compositional variations (Ti vs. other components, in apfu) for the obertiite-subgroup minerals from silicate part of the Elga-4 immiscible inclusion. 


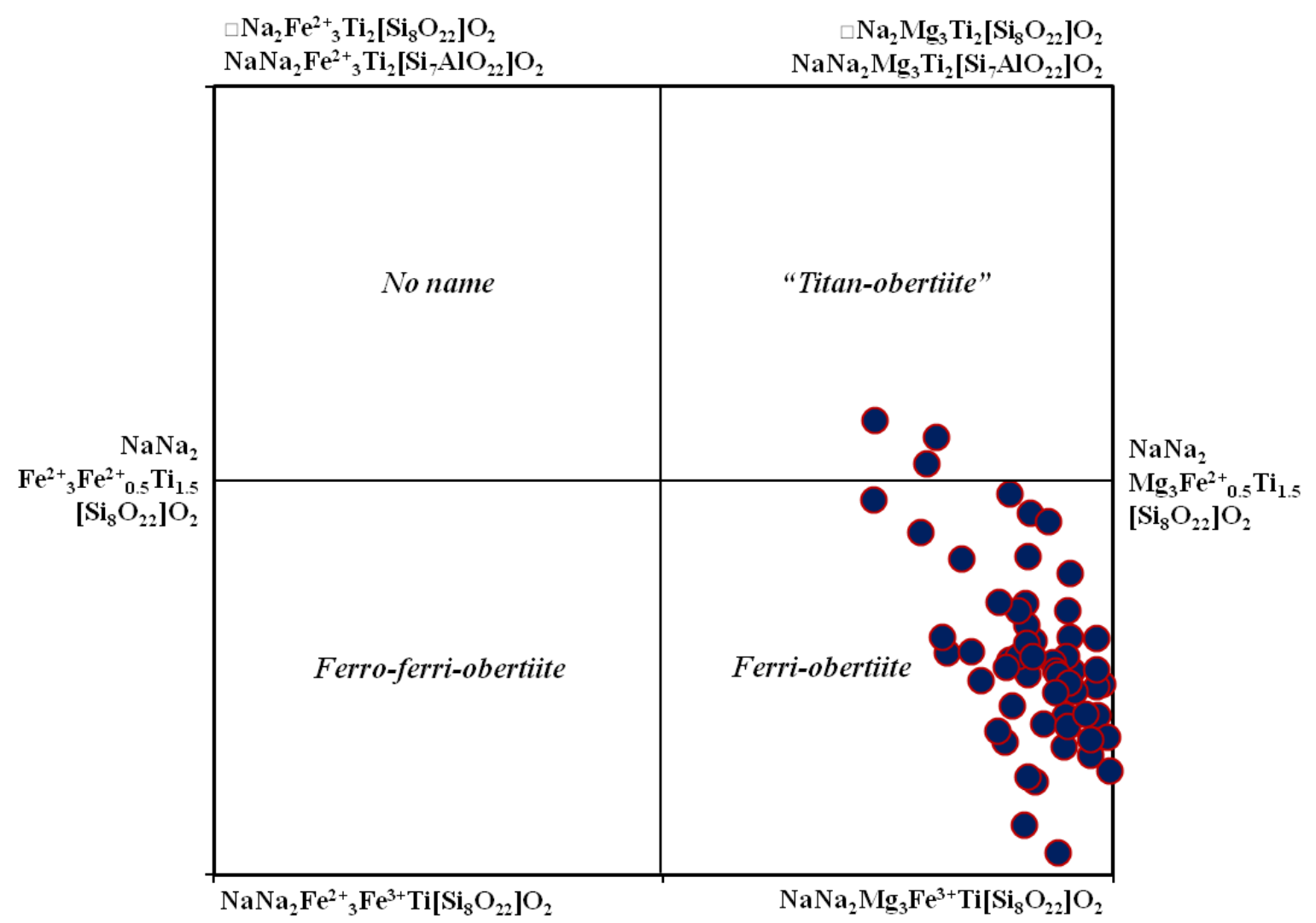

Figure 11. The proposed classification diagram for Ti-rich compositions of the obertiite subgroup (data for the Elga-4 immiscible inclusion).

\subsubsection{Minerals of the Aenigmatite-Subgroup (Sapphirine Supergroup)}

Minerals of this subgroup (aenigmatite, krinovite and wilkinsonite) rarely occur in meteorite environment [24]. The mineral close to aenigmatite was found in the Elga-4 studied immiscible inclusion, it is scarce and mainly confined to the periphery in the silicate part. Its averaged composition $(\mathrm{N}=11)$ is $\mathrm{Na}_{2.00}\left(\mathrm{Mg}_{2.67} \mathrm{Fe}^{2+}{ }_{2.00} \mathrm{Fe}^{3+}{ }_{0.16} \mathrm{Na}_{0.08} \mathrm{Mn}_{0.07} \mathrm{Cr}_{0.03}\right) \mathrm{Ti}_{0.99}\left(\mathrm{Si}_{5.91} \mathrm{Al}_{0.01} \mathrm{Fe}^{3+}{ }_{0.08} \mathrm{O}_{18}\right) \mathrm{O}_{2}$ indicating the predominance of $\mathrm{Mg}$ over $\mathrm{Fe}^{2+}$ (Table 5, Figure 10). According to the recent nomenclature for the sapphirine supergroup [40,41], this phase is related to the aenigmatite subgroup and its compositions correspond to the median values of the series aenigmatite $\mathrm{Na}_{2} \mathrm{Fe}^{2+}{ }_{5} \mathrm{TiSi}_{6} \mathrm{O}_{18} \mathrm{O}_{2}$-hypothetical phase $\mathrm{Na}_{2} \mathrm{Mg}_{5} \mathrm{TiSi}_{6} \mathrm{O}_{18} \mathrm{O}_{2}$ (Figure 12). The compositional variations are shown in Figure 12 and Table 5. The core-to-rim deviations within individual grains of the Elga mineral are negligible. Some surplus of $\mathrm{Na}\left(>2.0 \mathrm{apfu}\right.$ ) and $\mathrm{Fe}^{3+}$ may be explained by moderate isomorphism in octahedral environment: $2\left(\mathrm{Mg}, \mathrm{Fe}^{2+}\right) \leftrightarrow \mathrm{Na}^{+}+\mathrm{Fe}^{3+}$ (Figure 12).

Thus, the Elga meteorite seems to be a first occurrence for a potentially new mineral species $\mathrm{Na}_{2} \mathrm{Mg}_{5} \mathrm{TiSi}_{6} \mathrm{O}_{18} \mathrm{O}_{2}$ (Mg-analog of aenigmatite) assuming the $50 \%$ rule of IMA. Aenigmatitic mineral was previously mentioned in the Elga immiscible silicate-phosphate inclusions, but without clear identification by chemical composition [12,13].

In general, extraterrestrial aenigmatite was previously found in the clasts of the meteorites Allende, Kaidun and Adzhi-Bogdo (stone) [31,42-44], but all these compositions are dominant in the $\mathrm{Na}_{2} \mathrm{Fe}^{2+}{ }_{5} \mathrm{TiSi}_{6} \mathrm{O}_{18} \mathrm{O}_{2}$ end-member. It should be noted that phases with $0.40-0.48 \mathrm{~mol} \%$ of the $\mathrm{Na}_{2} \mathrm{Mg}_{5} \mathrm{TiSi}_{6} \mathrm{O}_{18} \mathrm{O}_{2}$ end-member were described in the terrestrial alkaline rocks $[45,46]$, but it was not enough to qualify them as new mineral species.

The majority of the Elga- 4 compositions contains $53-57$ mol.\% of the $\mathrm{Na}_{2} \mathrm{Mg}_{5} \mathrm{TiSi}_{6} \mathrm{O}_{18} \mathrm{O}_{2}$ end-member (ferroan "magnesioaenigmatite"); and only two analyses indicate values $44-47 \mathrm{~mol} . \%$ being magnesian aenigmatite (Table 5, Figure 12). 
Table 5. Chemical composition (WDS, wt.\%) of the aenigmatite-subgroup minerals from the Elga-4 immiscible inclusion in the Elga meteorite.

\begin{tabular}{|c|c|c|c|c|c|c|c|c|c|c|c|c|}
\hline \multirow[b]{2}{*}{ Area } & 1 & 2 & 3 & 4 & 5 & 6 & 7 & 8 & 9 & 10 & 11 & Mean \\
\hline & El4-13 & & & & & & & & \multicolumn{2}{|l|}{ E14-6 } & \multicolumn{2}{|l|}{ El4-N } \\
\hline $\mathrm{SiO}_{2}$ & 46.39 & 45.95 & 46.27 & 46.44 & 46.18 & 46.18 & 46.60 & 46.24 & 44.71 & 44.65 & 46.29 & 45.99 \\
\hline $\mathrm{TiO}_{2}$ & 10.20 & 10.33 & 10.29 & 10.36 & 10.29 & 10.10 & 10.09 & 10.14 & 10.47 & 10.59 & 10.20 & 10.28 \\
\hline $\mathrm{Cr}_{2} \mathrm{O}_{3}$ & 0.21 & 0.20 & 0.44 & 0.34 & 0.33 & 0.30 & 0.34 & 0.23 & 0.06 & 0.18 & 0.16 & 0.25 \\
\hline $\mathrm{Al}_{2} \mathrm{O}_{3}$ & n.d. & n.d. & n.d. & n.d. & n.d. & n.d. & n.d. & n.d. & 0.45 & 0.45 & n.d. & 0.08 \\
\hline $\mathrm{Fe}_{2} \mathrm{O}_{3}$ & 2.56 & 2.65 & 2.64 & 0.91 & 2.77 & 3.81 & 1.27 & 1.92 & 3.68 & 1.89 & 2.17 & 2.39 \\
\hline $\mathrm{FeO}$ & 17.53 & 17.74 & 17.68 & 19.30 & 18.08 & 16.01 & 18.77 & 18.78 & 20.12 & 22.59 & 18.38 & 18.63 \\
\hline $\mathrm{MnO}$ & 0.50 & 0.62 & 0.53 & 0.67 & 0.70 & 0.54 & 0.57 & 0.45 & 0.67 & 0.80 & 0.57 & 0.60 \\
\hline $\mathrm{MgO}$ & 14.59 & 14.20 & 14.58 & 14.18 & 13.91 & 15.06 & 14.53 & 14.43 & 12.01 & 11.34 & 14.60 & 13.95 \\
\hline $\mathrm{CaO}$ & 0.02 & n.d. & 0.03 & n.d. & n.d. & n.d. & n.d. & n.d. & n.d. & n.d. & n.d. & 0.01 \\
\hline $\mathrm{Na}_{2} \mathrm{O}$ & 8.47 & 8.44 & 8.43 & 8.24 & 8.53 & 8.55 & 8.24 & 8.21 & 8.42 & 8.10 & 8.24 & 8.35 \\
\hline Sum & 100.46 & 100.13 & 100.89 & 100.44 & 100.79 & 100.55 & 100.41 & 100.40 & 100.60 & 100.59 & 100.60 & 100.54 \\
\hline \multicolumn{13}{|c|}{ Formula based on 14 cations and 20 oxygens } \\
\hline $\mathrm{Si}$ & 5.935 & 5.915 & 5.906 & 5.964 & 5.918 & 5.891 & 5.973 & 5.938 & 5.820 & 5.848 & 5.929 & 5.913 \\
\hline $\mathrm{Al}$ & & & & & & & & & 0.070 & 0.069 & & 0.012 \\
\hline $\mathrm{Fe}^{3+}$ & 0.065 & 0.085 & 0.094 & 0.036 & 0.082 & 0.109 & 0.027 & 0.062 & 0.111 & 0.082 & 0.071 & 0.075 \\
\hline Sum & 6.000 & 6.000 & 6.000 & 6.000 & 6.000 & 6.000 & 6.000 & 6.000 & 6.000 & 6.000 & 6.000 & 6.000 \\
\hline $\mathrm{Ti}$ & 0.981 & 1.000 & 0.988 & 1.001 & 0.992 & 0.969 & 0.973 & 0.979 & 1.025 & 1.043 & 0.982 & 0.994 \\
\hline $\mathrm{Cr}$ & 0.021 & 0.020 & 0.044 & 0.035 & 0.033 & 0.030 & 0.034 & 0.023 & 0.006 & 0.019 & 0.016 & 0.026 \\
\hline $\mathrm{Fe}^{3+}$ & 0.182 & 0.171 & 0.160 & 0.052 & 0.185 & 0.256 & 0.095 & 0.124 & 0.250 & 0.104 & 0.138 & 0.156 \\
\hline $\mathrm{Fe}^{2+}$ & 1.875 & 1.909 & 1.888 & 2.073 & 1.937 & 1.708 & 2.012 & 2.017 & 2.190 & 2.474 & 1.968 & 2.003 \\
\hline $\mathrm{Mn}$ & 0.054 & 0.068 & 0.057 & 0.073 & 0.076 & 0.058 & 0.062 & 0.049 & 0.074 & 0.089 & 0.062 & 0.066 \\
\hline $\mathrm{Mg}$ & 2.783 & 2.725 & 2.774 & 2.715 & 2.657 & 2.864 & 2.776 & 2.763 & 2.331 & 2.214 & 2.788 & 2.673 \\
\hline $\mathrm{Na}$ & 0.103 & 0.106 & 0.089 & 0.052 & 0.119 & 0.115 & 0.048 & 0.044 & 0.125 & 0.057 & 0.046 & 0.082 \\
\hline Sum & 6.000 & 6.000 & 6.000 & 6.000 & 6.000 & 6.000 & 6.000 & 6.000 & 6.000 & 6.000 & 6.000 & 6.000 \\
\hline $\mathrm{Ca}$ & 0.002 & & 0.004 & & & & & & & & & 0.001 \\
\hline $\mathrm{Na}$ & 1.998 & 2.000 & 1.996 & 2.000 & 2.000 & 2.000 & 2.000 & 2.000 & 2.000 & 2.000 & 2.000 & 1.999 \\
\hline Sum & 2.000 & 2.000 & 2.000 & 2.000 & 2.000 & 2.000 & 2.000 & 2.000 & 2.000 & 2.000 & 2.000 & 2.000 \\
\hline \multicolumn{13}{|c|}{ End-members (mol.\%) } \\
\hline Mg-Aen & 55.66 & 54.50 & 55.49 & 54.30 & 53.15 & 57.28 & 55.53 & 55.25 & 46.61 & 44.28 & 55.75 & 53.46 \\
\hline Aen & 37.51 & 38.19 & 37.75 & 41.47 & 38.75 & 34.16 & 40.23 & 40.35 & 43.80 & 49.49 & 39.37 & 40.07 \\
\hline Others & 6.83 & 7.31 & 6.76 & 4.23 & 8.10 & 8.56 & 4.24 & 4.40 & 9.59 & 6.23 & 4.88 & 6.47 \\
\hline
\end{tabular}

$\mathrm{K}_{2} \mathrm{O}, \mathrm{P}_{2} \mathrm{O}_{5}, \mathrm{~V}_{2} \mathrm{O}_{3}, \mathrm{~F}, \mathrm{Cl}$ and $\mathrm{ZnO}$ are below detection limits $(<0.005$ wt.\%); n.d.- -not detected; $\mathrm{FeO}$ and $\mathrm{Fe}_{2} \mathrm{O}_{3}$ are calculated on charge balance. Aen-aenigmatite $\mathrm{NaFe}^{2+}{ }_{5} \mathrm{Ti}_{(}\left(\mathrm{Si}_{6} \mathrm{O}_{18}\right) \mathrm{O}_{2}, \mathrm{Mg}$-Aen-hypothetical

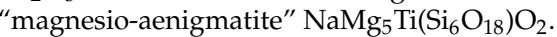
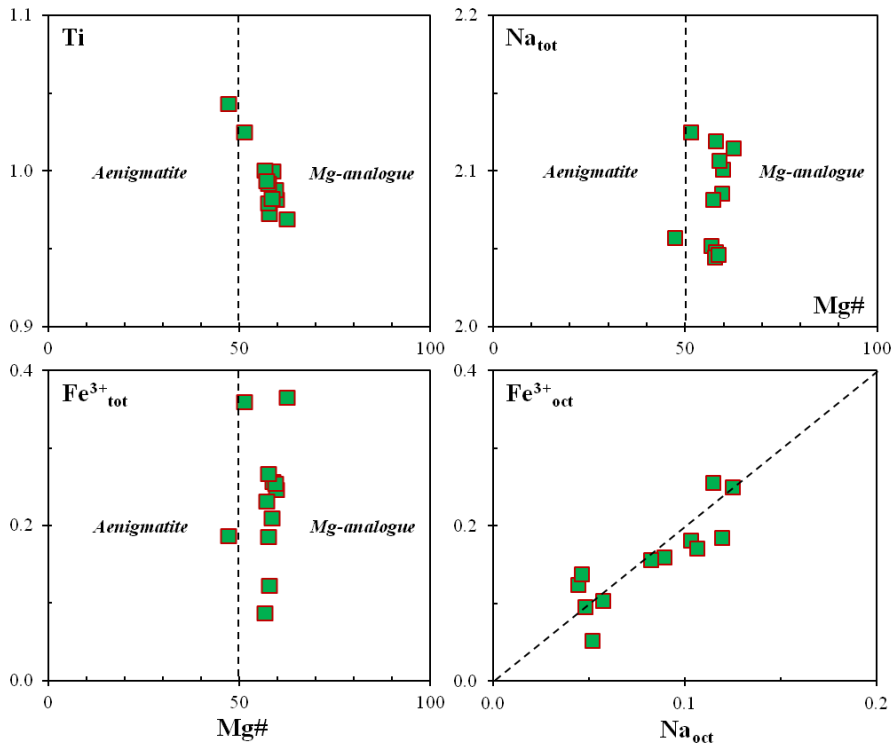

Figure 12. Compositional variations (in apfu) for the aenigmatite-subgroup minerals from the silicate part of the Elga-4 immiscible inclusion. $\mathrm{Mg} \#=\mathrm{Mg} /\left(\mathrm{Mg}+\mathrm{Fe}^{2+}\right)$. 


\subsubsection{Orthopyroxene}

As mentioned above, abundant low-Ca pyroxene is confined to the silicate-natrophosphate contact (Figures 5 and 7) and also dispersed in the silicate part. Unfortunately, the position of the studied Elga silicate inclusion in Fe-Ni metal cannot give a possibility to determine optical and structural features for such pyroxene (orthorhombic or monoclinic). According to previous data for the Elga meteorite $[5,8,15]$, it seems to be orthopyroxene. In general, it is enstatite (Table 6) and its compositional variations for all grains are essential: from $\mathrm{En}_{81.3} \mathrm{Fs}_{17.4} \mathrm{Wo}_{1.3}$ to $\mathrm{En}_{65.3} \mathrm{Fs}_{33.0} \mathrm{Wo}_{1.7}$. The core-to-rim deviations within individual enstatite grains are sometimes drastic (especially for zoned grains in the silicate-phosphate contact) and directed to increasing of the ferrosilite end-member (Table 6, Figure 6, Figure 9 and Figure S12). All enstatites also contain minor $\mathrm{TiO}_{2}$ (up to 0.4), $\mathrm{Cr}_{2} \mathrm{O}_{3}$ (up to 0.5), $\mathrm{Al}_{2} \mathrm{O}_{3}$ (up to 0.2), $\mathrm{Fe}_{2} \mathrm{O}_{3}$ (calculated, up to 1.3), $\mathrm{MnO}$ (up to 1.7) and $\mathrm{Na}_{2} \mathrm{O}$ (up to $0.3 \mathrm{wt}$ \%) (Table 6).

Table 6. Chemical composition (WDS, wt.\%) of enstatite from the Elga-4 immiscible inclusion in the Elga meteorite.

\begin{tabular}{|c|c|c|c|c|c|c|c|}
\hline & 1 & 2 & & 3 & 4 & $5 \mathrm{c}$ & $5 \mathrm{r}$ \\
\hline Position & SP & CONT & & SP & SP & CONT & CONT \\
\hline \multirow[t]{2}{*}{ Area } & Elga-4 & Elga-4 & & Elga-4 & E14-5-2 & E14-5-3 & El4-5-3 \\
\hline & $\mathbf{N}=3$ & $N=19$ & sd & $\mathbf{N}=3$ & $N=1$ & $\mathrm{~N}=1$ & $N=1$ \\
\hline $\mathrm{SiO}_{2}$ & 55.69 & 56.12 & 0.43 & 53.94 & 55.41 & 56.56 & 54.37 \\
\hline $\mathrm{TiO}_{2}$ & 0.41 & 0.28 & 0.06 & n.d. & 0.27 & 0.28 & n.d. \\
\hline $\mathrm{Cr}_{2} \mathrm{O}_{3}$ & 0.54 & 0.34 & 0.08 & n.d. & 0.34 & 0.32 & n.d. \\
\hline $\mathrm{Al}_{2} \mathrm{O}_{3}$ & n.d. & 0.03 & 0.05 & 0.11 & 0.20 & n.d. & 0.11 \\
\hline $\mathrm{Fe}_{2} \mathrm{O}_{3}$ & 0.82 & 0.98 & 0.81 & 1.31 & 0.27 & 0.53 & 0.95 \\
\hline $\mathrm{FeO}$ & 11.39 & 10.16 & 0.99 & 18.62 & 14.14 & 9.81 & 18.24 \\
\hline $\mathrm{MnO}$ & 0.90 & 0.75 & 0.09 & 1.66 & 0.65 & 0.75 & 1.54 \\
\hline $\mathrm{MgO}$ & 29.42 & 30.97 & 0.74 & 23.84 & 27.90 & 31.41 & 24.41 \\
\hline $\mathrm{CaO}$ & 0.70 & 0.43 & 0.08 & 0.34 & 0.50 & 0.43 & 0.29 \\
\hline $\mathrm{Na}_{2} \mathrm{O}$ & 0.29 & 0.15 & 0.06 & 0.28 & 0.29 & 0.17 & 0.29 \\
\hline Sum & 100.17 & 100.22 & & 100.10 & 99.97 & 100.26 & 100.20 \\
\hline \multicolumn{8}{|c|}{ Formula based on 4 cations and 6 oxygens } \\
\hline $\mathrm{Si}$ & 1.980 & 1.979 & & 1.989 & 1.990 & 1.987 & 1.995 \\
\hline $\mathrm{Al}$ & & 0.001 & & 0.005 & 0.008 & & 0.005 \\
\hline $\mathrm{Fe}^{3+}$ & 0.020 & 0.020 & & 0.006 & 0.001 & 0.013 & 0.000 \\
\hline Sum & 2.000 & 2.000 & & 2.000 & 2.000 & 2.000 & 2.000 \\
\hline $\mathrm{Ti}$ & 0.011 & 0.008 & & & 0.007 & 0.007 & \\
\hline $\mathrm{Cr}$ & 0.015 & 0.010 & & & 0.010 & 0.009 & \\
\hline $\mathrm{Fe}^{3+}$ & 0.002 & 0.006 & & 0.031 & 0.006 & 0.001 & 0.026 \\
\hline $\mathrm{Fe}^{2+}$ & 0.339 & 0.300 & & 0.574 & 0.425 & 0.288 & 0.560 \\
\hline $\mathrm{Mn}$ & 0.027 & 0.022 & & 0.052 & 0.020 & 0.022 & 0.048 \\
\hline $\mathrm{Mg}$ & 1.559 & 1.628 & & 1.310 & 1.493 & 1.644 & 1.335 \\
\hline $\mathrm{Ca}$ & 0.027 & 0.016 & & 0.014 & 0.019 & 0.016 & 0.011 \\
\hline $\mathrm{Na}$ & 0.020 & 0.010 & & 0.020 & 0.020 & 0.012 & 0.021 \\
\hline Sum & 2.000 & 2.000 & & 2.000 & 2.000 & 2.000 & 2.000 \\
\hline \multicolumn{8}{|c|}{ End-members (mol.\%) } \\
\hline En & 78.20 & 81.30 & & 65.31 & 75.25 & 82.35 & 66.72 \\
\hline Fs & 19.46 & 17.39 & & 33.03 & 22.76 & 16.26 & 31.68 \\
\hline Wo & 2.34 & 1.32 & & 1.66 & 1.99 & 1.39 & 1.60 \\
\hline
\end{tabular}

$\mathrm{P}_{2} \mathrm{O}_{5}, \mathrm{SrO}, \mathrm{V}_{2} \mathrm{O}_{3}, \mathrm{~K}_{2} \mathrm{O}$ and $\mathrm{ZnO}$ are below detection limits ( $\left.<0.005 \mathrm{wt} . \%\right) ;$ n.d.—not detected; sd-standard deviation. $\mathrm{FeO}$ and $\mathrm{Fe}_{2} \mathrm{O}_{3}$ are calculated on charge balance. SP—silicate part of the inclusion; CONT—contact between silicate and natrophosphate parts. En-enstatite; Fs-ferrosilite; Wo-wollastonite. 1-2-Mg-rich compositions; 3-Fe-rich composition; 4-intermediate composition; 5 (c, r) - core and rim of zoned grain. 


\subsubsection{Na-Ca-Cr-Ti-Mg-Clinopyroxenes}

These exotic clinopyroxenes are confined to the silicate-natrophosphate contact in the Elga- 4 inclusion and occur both in the silicate and in phosphate sides (Figure 6, Figure 7, Figure 9, Figures S8 and S10-S12). Unfortunately, we cannot obtain more analyses for the mineral from the contact and natrophosphate globule because of minute size of most grains $(<5 \mu \mathrm{m}$, Figure 9, Figures S10 and S12). All compositions from the Elga-4 inclusion are poor in alumina and correspond to the series of diopside $\mathrm{Ca}(\mathrm{Mg}, \mathrm{Fe}) \mathrm{Si}_{2} \mathrm{O}_{6}$ - kosmochlor $\mathrm{NaCrSi}_{2} \mathrm{O}_{6}$-hypothetical $\mathrm{Na}(\mathrm{Mg}, \mathrm{Fe})_{0.5} \mathrm{Ti}_{0.5} \mathrm{Si}_{2} \mathrm{O}_{6}$ with minor content of the aegirine $\mathrm{NaFe}^{3+} \mathrm{Si}_{2} \mathrm{O}_{6}$ and hedenbergite $\mathrm{CaFe}^{2+} \mathrm{Si}_{2} \mathrm{O}_{6}$ end-members (Table 7). All this does not allow providing correct classification of these clinopyroxenes within the pyroxene supergroup [47]. Although the compositional inhomogenity of some grains is indicated on BSE images and elemental maps (Figure 6, Figures S8, S11 and S12), it is impossible to establish the sequence and tendency in the changing of the end-member contents during crystal growth. In general, clinopyroxene from the silicate part is richer in the kosmochlor end-member, the mineral from the contact is abundant in the diopside and aegirine end-members and the phase from the phosphate globule has high content of the hypothetical $\mathrm{Na}(\mathrm{Mg}, \mathrm{Fe})_{0.5} \mathrm{Ti}_{0.5} \mathrm{Si}_{2} \mathrm{O}_{6}$ end-member (Figure 13).

Table 7. Chemical composition (WDS, wt.\%) of complex clinopyroxenes from the Elga-4 immiscible inclusion in the Elga meteorite.

\begin{tabular}{|c|c|c|c|c|c|c|c|c|c|c|c|c|c|}
\hline Position & SP & SP & SP & SP & SP & SP & SP & CONT & CONT & CONT & NFG & NFG & NFG \\
\hline \multirow[t]{2}{*}{ Area } & El4-5-1 & E14-5-1 & E14-5-1 & El4-5-2 & El4-5-2 & El4-5-2 & El4-5-2 & El4-5-3 & El4-5-3 & E14-1 & E14-6x & El4-6x & El4-6x \\
\hline & $\mathbf{N}=3$ & $\mathrm{~N}=4$ & $\mathrm{~N}=4$ & $\mathrm{~N}=2$ & $\mathrm{~N}=2$ & $\mathrm{~N}=2$ & $\mathbf{N}=2$ & $\mathrm{~N}=1$ & $N=1$ & $\mathbf{N}=\mathbf{1}$ & $N=2$ & $N=2$ & $\mathrm{~N}=2$ \\
\hline $\mathrm{TiO}_{2}$ & 4.28 & 3.34 & 3.74 & 5.28 & 4.89 & 2.29 & 4.07 & 3.15 & 2.92 & 4.55 & 12.05 & 10.61 & 9.38 \\
\hline $\mathrm{V}_{2} \mathrm{O}_{3}$ & n.d. & n.d. & n.d. & n.d. & n.d. & n.d. & n.d. & n.d. & n.d. & n.d. & 0.11 & 0.08 & 0.08 \\
\hline $\mathrm{Cr}_{2} \mathrm{O}_{3}$ & 10.89 & 16.92 & 14.94 & 17.58 & 17.25 & 10.06 & 15.41 & 9.30 & 7.54 & 7.33 & 10.87 & 12.22 & 11.04 \\
\hline $\mathrm{FeO}$ & 1.65 & 0.94 & 3.11 & 1.64 & 2.23 & 0.03 & 0.99 & 0.05 & 3.24 & 0.00 & 1.41 & 2.60 & 0.33 \\
\hline $\mathrm{MnO}$ & 0.19 & 0.23 & 0.30 & 0.20 & 0.21 & 0.22 & 0.27 & 0.23 & 0.44 & 0.27 & 0.20 & 0.17 & 0.21 \\
\hline $\mathrm{MgO}$ & 9.51 & 5.64 & 6.34 & 5.32 & 5.16 & 10.48 & 6.24 & 9.24 & 9.45 & 10.33 & 4.44 & 4.27 & 4.78 \\
\hline $\mathrm{CaO}$ & 11.57 & 6.78 & 6.71 & 5.07 & 5.62 & 13.41 & 7.10 & 11.15 & 10.26 & 12.39 & 3.08 & 2.90 & 4.54 \\
\hline $\mathrm{Na}_{2} \mathrm{O}$ & 7.53 & 10.09 & 9.42 & 11.03 & 10.65 & 6.59 & 9.89 & 7.70 & 7.10 & 7.11 & 13.14 & 12.80 & 12.33 \\
\hline Sum & 100.25 & 99.96 & 100.15 & 100.35 & 99.88 & 100.06 & 100.03 & 101.14 & 100.20 & 99.87 & 99.94 & 100.20 & 99.90 \\
\hline $\mathrm{Fe}^{3+}$ & 0.011 & 0.001 & 0.001 & 0.007 & 0.002 & 0.001 & 0.004 & 0.034 & 0.002 & 0.039 & 0.020 & 0.017 & 0.001 \\
\hline Sum & 2.000 & 2.000 & 2.000 & 2.000 & 2.000 & 2.000 & 2.000 & 2.000 & 2.000 & 2.000 & 2.000 & 2.000 & 2.000 \\
\hline $\mathrm{Ti}$ & 0.118 & 0.093 & 0.105 & 0.146 & 0.137 & 0.063 & 0.113 & 0.087 & 0.081 & 0.126 & 0.332 & 0.293 & 0.259 \\
\hline $\mathrm{Cr}+\mathrm{V}$ & 0.316 & 0.497 & 0.439 & 0.513 & 0.507 & 0.292 & 0.451 & 0.269 & 0.221 & 0.213 & 0.318 & 0.357 & 0.323 \\
\hline $\mathrm{Fe}^{3+}$ & 0.000 & 0.064 & 0.052 & 0.001 & 0.004 & 0.069 & 0.059 & 0.148 & 0.147 & 0.090 & 0.002 & 0.003 & 0.082 \\
\hline $\mathrm{Fe}^{2+}$ & 0.051 & 0.029 & 0.097 & 0.051 & 0.069 & 0.001 & 0.031 & 0.002 & 0.100 & 0.000 & 0.043 & 0.080 & 0.010 \\
\hline $\mathrm{Mn}$ & 0.006 & 0.007 & 0.010 & 0.006 & 0.007 & 0.007 & 0.008 & 0.007 & 0.014 & 0.008 & 0.006 & 0.005 & 0.007 \\
\hline $\mathrm{Mg}$ & 0.519 & 0.312 & 0.351 & 0.293 & 0.286 & 0.573 & 0.344 & 0.504 & 0.521 & 0.567 & 0.243 & 0.234 & 0.262 \\
\hline Sum & 1.009 & 1.003 & 1.053 & 1.010 & 1.009 & 1.004 & 1.008 & 1.017 & 1.084 & 1.004 & 0.945 & 0.953 & 0.943 \\
\hline $\mathrm{Ca}$ & 0.455 & 0.270 & 0.267 & 0.201 & 0.224 & 0.527 & 0.282 & 0.437 & 0.407 & 0.489 & 0.121 & 0.114 & 0.179 \\
\hline $\mathrm{Na}$ & 0.536 & 0.727 & 0.679 & 0.789 & 0.767 & 0.469 & 0.710 & 0.546 & 0.509 & 0.507 & 0.934 & 0.913 & 0.878 \\
\hline
\end{tabular}

$\mathrm{P}_{2} \mathrm{O}_{5}, \mathrm{SrO}, \mathrm{K}_{2} \mathrm{O}$ and $\mathrm{ZnO}$ are below detection limits $\left(<0.005\right.$ wt.\%); n.d.-not detected. $\mathrm{FeO}$ and $\mathrm{Fe}_{2} \mathrm{O}_{3}$ are calculated on charge balance. $\mathrm{SP}$ - silicate part of the inclusion; $\mathrm{CONT}$ - on the contact between silicate and natrophosphate parts; NFG—natrophosphate globule; "Na-Ti-cpx"—hypothetical $\mathrm{Na}(\mathrm{Mg}, \mathrm{Fe})_{0.5} \mathrm{Ti}_{0.5} \mathrm{Si}_{2} \mathrm{O}_{6}$. 


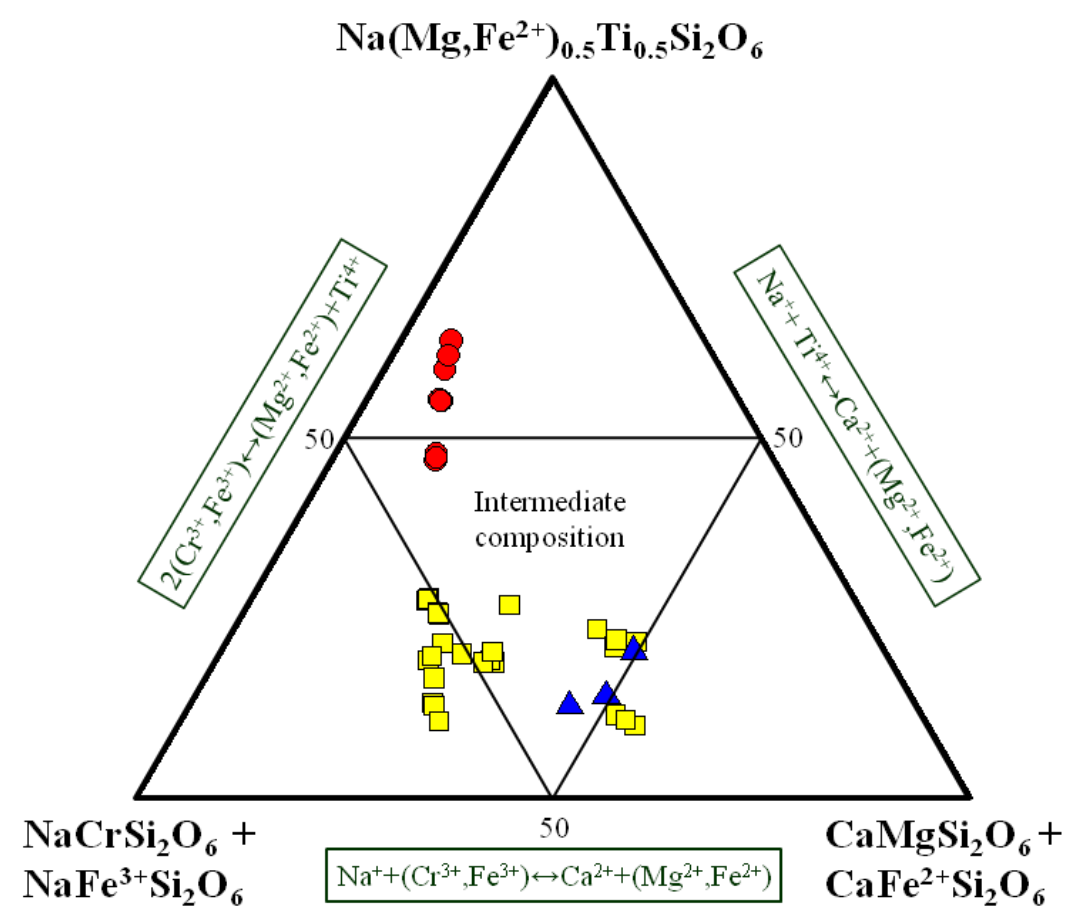

Figure 13. Complex clinopyroxenes from the Elga-4 immiscible inclusion on the ternary diagram and their isomorphic substitutions. Symbols for clinopyroxenes: squares-silicate part of the inclusion; triangles—silicate-natrophosphate contact; circles—natrophosphate globule.

It should be noted that well-known clinopyroxenes (diopside, hedenbergite, kosmochlor, etc.) are common for meteorites $[24,48,49]$, whereas the diopside-kosmochlor join and more complex solutions are exceptionally rare phenomena in natural conditions, even in terrestrial environments [50-55]. In this context, the appearance of complex clinopyroxenes in the Elga meteorite is very unique and exotic in meteorites. The diopside-kosmochlor join was previously mentioned in the Morasko meteorite [56-58].

Clinopyroxene from the natrophosphate globule of the Elga-4 inclusion contain 47-64 mol.\% of the $\mathrm{Na}(\mathrm{Mg}, \mathrm{Fe})_{0.5} \mathrm{Ti}_{0.5} \mathrm{Si}_{2} \mathrm{O}_{6}$ end-member (Table 7 and Figure 13) and this gave reason to consider this composition as a potentially new mineral species $\mathrm{Na}(\mathrm{Mg}, \mathrm{Fe})_{0.5} \mathrm{Ti}_{0.5} \mathrm{Si}_{2} \mathrm{O}_{6}$. However, like with the obertiite-subgroup mineral, it needs further detailed studies of the crystal structure and chemical composition with precise determination of $\mathrm{TiO}_{2}$ and $\mathrm{Ti}_{2} \mathrm{O}_{3}, \mathrm{FeO}$ and $\mathrm{Fe}_{2} \mathrm{O}_{3}$, and $\mathrm{Li}_{2} \mathrm{O}$. All these components may essentially influence during the formula calculation.

\subsubsection{Na-Ca-Mg-Fe-Orthophosphates}

Brianite $\mathrm{Na}_{2} \mathrm{CaMg}\left(\mathrm{PO}_{4}\right)_{2}$ and czochralskiite $\mathrm{Na}_{4} \mathrm{Ca}_{3} \mathrm{Mg}\left(\mathrm{PO}_{4}\right)_{4}$ are the main orthophosphates within the natrophosphate globule in the Elga-4 immiscible inclusion. Marićite $\mathrm{NaFe}\left(\mathrm{PO}_{4}\right)$ is minor mineral in the globule (Figure 7, Figure 9 and Figures S10-S12). The above minerals are very scarce in both extraterrestrial and terrestrial environments [57-63]. If maricite was first discovered in bedded shales and sideritic limestones of the Big Fish River area (Yukon Territory, Canada) [60] and then in meteorites [57,58,61-63], other minerals were first identified in iron meteorites [12,13,17,57-59]. In general, meteorite Elga is the second occurrence for czochralskiite, the third locality for brianite and the sixth occurrence for marićite. Chemical compositions of $\mathrm{Na}-\mathrm{Ca}-\mathrm{Mg}$-Fe-orthophosphates from the Elga-4 inclusion are given in Table 8. They are very similar to composition of same phosphates found in other immiscible inclusions in the Elga meteorite [13]. Unlike the Morasko holotype mineral [58], the Elga czochralskiite is richer in $\mathrm{FeO}(2.3-5.1)$ and $\mathrm{MnO}(0.4-1.5 \mathrm{wt} . \%)$. Brianite from the Elga meteorite also contains high $\mathrm{FeO}(3.0-4.3)$ and $\mathrm{MnO}(0.3-0.7 \mathrm{wt} . \%)$ in respect to the holotype mineral from the Dayton meteorite [59]. The Elga marićite is more abundant in $\mathrm{MgO}$ (5.3-6.2) and $\mathrm{CaO}$ (0.5-1.5 wt.\%) in comparison with terrestrial and meteoritic mineral [60-62]. 


\subsubsection{Other Minerals}

Chromite is an accessory mineral in the Elga-4 immiscible inclusion and confined to the contact between silicate and natrophosphate parts (Figure 6, Figure 9 and Figure S10). Unfortunately, we cannot obtain the precise analyses for this mineral due to the very small size $(<3 \mu \mathrm{m})$ and entrapment of neighboring phases. Anyway, it is a Fe-Cr-dominant phase ( $\mathrm{FeO}>25, \mathrm{Cr}_{2} \mathrm{O}_{3}>55.2 \mathrm{wt}$. \%) and contains $\mathrm{TiO}_{2}$ (0.5), $\mathrm{MnO}$ (1.7), $\mathrm{ZnO}(2.7) \mathrm{MgO}(2.2)$ and $\mathrm{Al}_{2} \mathrm{O}_{3}$ (0.9 wt.\%). That is similar to chromite found in another immiscible inclusion in the Elga meteorite [13].

Fe-rich chlorite and Na-rich hydrated Fe-phosphate are mainly restricted to the silicate part of the Elga-4 inclusion (Figure 6, Figure 8 and Figure S9). The chemical composition of chlorite is (in wt.\%, $\mathrm{N}=5$ ): $\mathrm{SiO}_{2}-36.90 ; \mathrm{Al}_{2} \mathrm{O}_{3}-3.02 ; \mathrm{FeO}_{\text {tot }}-33.68 ; \mathrm{MnO}-0.23 ; \mathrm{MgO}-1.70 ; \mathrm{CaO}-0.22 ; \mathrm{Na}_{2} \mathrm{O}-0.69 ; \mathrm{K}_{2} \mathrm{O}-0.50$. That seems to be related to chamosite $\mathrm{Fe}_{5} \mathrm{Al}\left[\mathrm{AlSi}_{3} \mathrm{O}_{10}\right](\mathrm{OH})_{8}$. Hydrated Fe-phosphate is probably close to vivianite $\mathrm{Fe}^{2+}{ }_{3}\left(\mathrm{PO}_{4}\right)_{2} \cdot 8 \mathrm{H}_{2} \mathrm{O}$ and contains $\mathrm{Na}_{2} \mathrm{O}>2.2 \mathrm{wt}$. $\%$. Its chemical composition is given in Table 8. The same phase is also mentioned in other silicate inclusions of the Elga meteorite [15]. This mineral seems to be an alteration product of former anhydrous Na-Fe-phosphate.

Table 8. Chemical composition (WDS, wt.\%) of Na-rich phosphates from natrophosphate globule of the Elga-4 immiscible inclusion in the Elga meteorite.

\begin{tabular}{|c|c|c|c|c|c|c|c|c|c|c|c|c|c|}
\hline \multirow[t]{2}{*}{ Mineral } & \multicolumn{3}{|c|}{ Czochralskiite } & \multicolumn{4}{|c|}{ Brianite } & \multicolumn{4}{|c|}{ Marićite } & \multicolumn{2}{|r|}{ NFP } \\
\hline & $\mathrm{N}=32$ & sd & $\min$ & $\max$ & $N=23$ & sd & $\min$ & $\max$ & $N=16$ & sd & $\min$ & $\max$ & $\mathrm{N}=4$ \\
\hline $\mathrm{SiO}_{2}$ & 0.13 & 0.14 & 0.00 & 0.75 & 0.09 & 0.09 & 0.00 & 0.44 & 0.13 & 0.19 & 0.00 & 0.67 & 0.54 \\
\hline $\mathrm{P}_{2} \mathrm{O}_{5}$ & 45.16 & 0.35 & 44.38 & 45.86 & 46.68 & 46.68 & 45.62 & 47.12 & 41.88 & 0.50 & 41.10 & 42.46 & 31.30 \\
\hline $\mathrm{FeO}$ & 3.31 & 0.70 & 2.27 & 5.07 & 3.39 & 3.39 & 2.95 & 4.23 & 26.74 & 0.42 & 25.80 & 27.74 & 34.58 \\
\hline $\mathrm{MnO}$ & 0.64 & 0.21 & 0.41 & 1.48 & 0.48 & 0.48 & 0.26 & 0.67 & 5.81 & 0.28 & 5.34 & 6.17 & 0.59 \\
\hline $\mathrm{MgO}$ & 4.88 & 0.34 & 4.22 & 5.64 & 11.03 & 11.03 & 10.40 & 11.89 & 5.65 & 0.32 & 5.28 & 6.24 & 3.77 \\
\hline $\mathrm{CaO}$ & 26.03 & 0.59 & 25.00 & 27.06 & 17.76 & 17.76 & 17.40 & 18.85 & 0.77 & 0.25 & 0.52 & 1.46 & 2.26 \\
\hline $\mathrm{SrO}$ & 0.10 & 0.05 & 0.00 & 0.18 & 0.34 & 0.34 & 0.10 & 0.53 & 0.09 & 0.06 & 0.00 & 0.17 & \\
\hline $\mathrm{Na}_{2} \mathrm{O}$ & 19.85 & 0.25 & 19.50 & 20.45 & 20.27 & 20.27 & 19.87 & 20.60 & 18.90 & 0.29 & 18.60 & 19.60 & 2.22 \\
\hline Sum & 100.10 & & & & 100.04 & & & & 99.98 & & & & 76.37 \\
\hline $\begin{array}{l}\text { Formula } \\
\text { based on }\end{array}$ & 16 oxy & & & & 8 oxy & & & & 4 oxy & & & & \\
\hline $\mathrm{Si}$ & 0.014 & & & & 0.004 & & & & 0.004 & & & & \\
\hline $\mathrm{P}$ & 3.981 & & & & 2.007 & & & & 0.986 & & & & \\
\hline $\mathrm{Fe}$ & 0.288 & & & & 0.144 & & & & 0.622 & & & & \\
\hline $\mathrm{Mn}$ & 0.056 & & & & 0.021 & & & & 0.137 & & & & \\
\hline $\mathrm{Mg}$ & 0.758 & & & & 0.835 & & & & 0.234 & & & & \\
\hline $\mathrm{Ca}$ & 2.907 & & & & 0.967 & & & & 0.023 & & & & \\
\hline $\mathrm{Sr}$ & 0.006 & & & & 0.010 & & & & 0.001 & & & & \\
\hline $\mathrm{Na}$ & 4.008 & & & & 1.996 & & & & 1.019 & & & & \\
\hline Sum cations & 12.018 & & & & 5.983 & & & & 3.027 & & & & \\
\hline
\end{tabular}

$\mathrm{Al}_{2} \mathrm{O}_{3}, \mathrm{TiO}_{2}, \mathrm{Cr}_{2} \mathrm{O}_{3}, \mathrm{SO}_{3}, \mathrm{~F}, \mathrm{Cl}, \mathrm{K}_{2} \mathrm{O}$ and $\mathrm{ZnO}$ are below detection limits (<0.005 wt.\%). NFP-hydrated sodium-containing iron phosphate (sum includes $0.23 \mathrm{wt} . \% \mathrm{Al}_{2} \mathrm{O}_{3}$ and $0.89 \mathrm{wt} . \% \mathrm{~K}_{2} \mathrm{O}$ ). $\mathrm{N}$, sd, min, max-average, standard deviation, minimal and maximal values.

\section{Raman Spectroscopy for Minerals of the Elga-4 Inclusion}

The main minerals in the Elga-4 inclusion were also studied by Raman spectroscopy. The unoriented Raman spectra of minerals are shown in Figures 14-16 and Figures S13-S14.

In general, the intensity of the Raman bands depends on the orientation of mineral grains with respect to the laser incident beam. Commonly, their orientation is not under control; therefore, the intensity of the resultant Raman bands is not indicative of the amounts of the different chemical components in the studied minerals. Nevertheless, the shifting of the Raman bands characteristic for particular minerals may outline the changing in chemical compositions. 

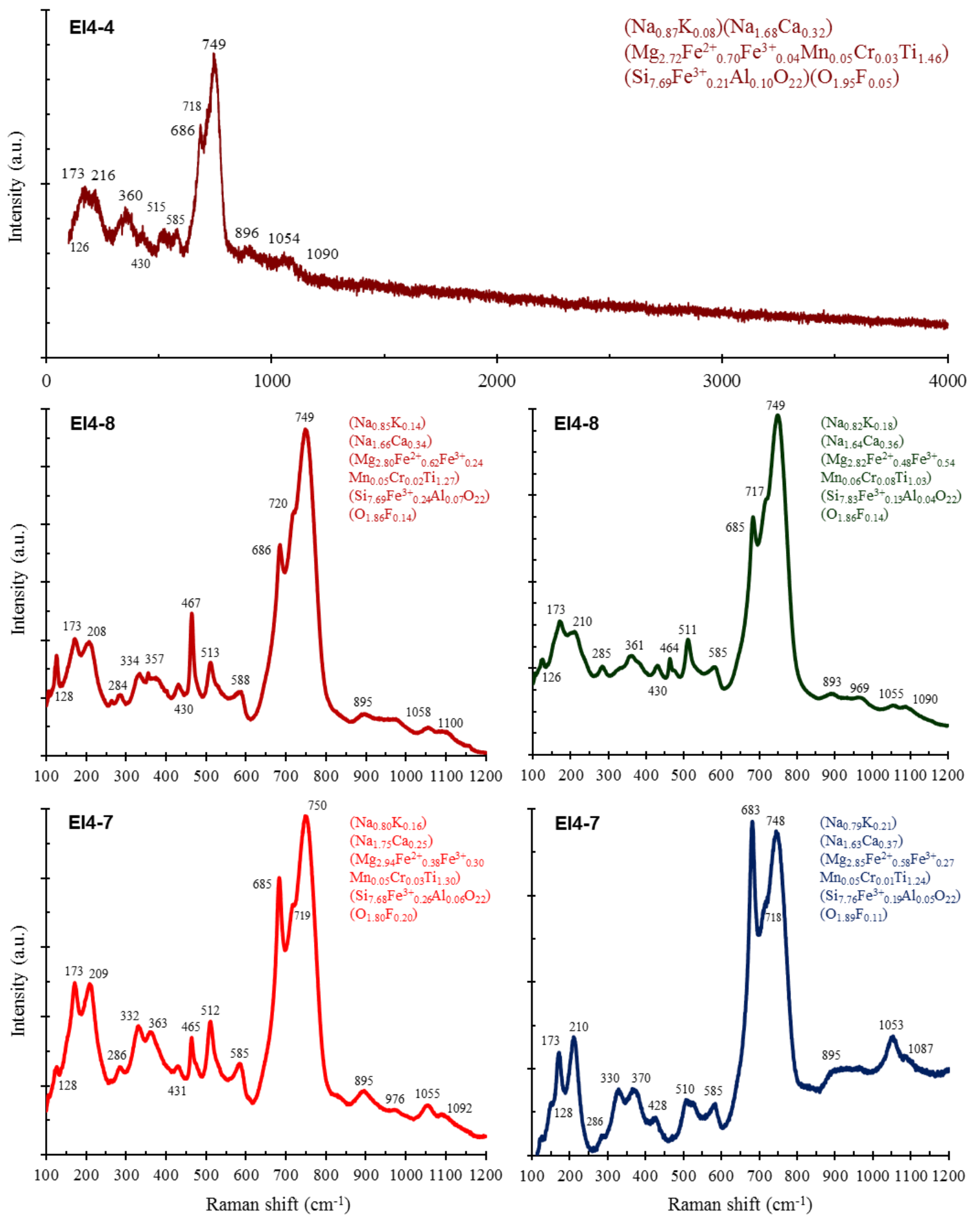

Figure 14. Raman spectra of the obertiite-subgroup minerals from the Elga- 4 immiscible inclusion.

Most silicates show complex chemical formulas and different electrovalence substitutions in equivalent crystallographic sites. In general, the characteristic frequencies of the Raman spectra for silicates (for example, amphiboles) may be interpreted as: $100-300 \mathrm{~cm}^{-1}$-lattice vibrations modes; $300-625 \mathrm{~cm}^{-1}$ - vibrational modes of the non-tetrahedral cations, bending modes of $\mathrm{SiO}_{4}$ tetrahedra, $\mathrm{OH}$ libration and translation modes, and translational $\mathrm{M}-\mathrm{OH}$ modes; $625-750 \mathrm{~cm}^{-1}$-symmetric stretching modes of bridging oxygen atoms that link the adjacent $\mathrm{SiO}_{4}$ tetrahedra $\left(\mathrm{Si}-\mathrm{O}_{\mathrm{b}}-\mathrm{Si}\right)$; $750-950 \mathrm{~cm}^{-1}$ —modes of symmetric $\mathrm{SiO}_{4}$ stretching; $950-1000 \mathrm{~cm}^{-1}$-modes of antisymmetric $\mathrm{SiO}_{4}$ 
stretching; $1000-1215 \mathrm{~cm}^{-1}$ —modes of antisymmetric $\mathrm{Si}-\mathrm{O}_{\mathrm{b}}-\mathrm{Si}$ bond stretching; $3600-3800 \mathrm{~cm}^{-1}-\mathrm{OH}$ bond stretching modes [64-66].

Raman measurements for the Elga obertiite-subgroup minerals (Figure 14) did not indicate any evident bands in the $3000-4000 \mathrm{~cm}^{-1}$ region evidencing about the possible absence of the OH-groups. Unfortunately, the Raman spectra for Fe-rich minerals of the obertiite subgroup have not been reported anywhere, except data for mangani-obertiite $\mathrm{NaNa}_{2} \mathrm{Mg}_{3} \mathrm{Mn}^{3+} \mathrm{Ti}\left(\mathrm{Si}_{8} \mathrm{O}_{22}\right) \mathrm{O}_{2}$ from the RRUFF project [67]. All spectra show the same suite of main characteristic signals in the $100-1200 \mathrm{~cm}^{-1}$ region: $126-128$, 208-216, 330-334, 357-370, 465-467, 510-513, 683-686 (strong), 717-720 (strong, shoulder), 748-750 (strongest) and 1053-1058 $\mathrm{cm}^{-1}$ (Figure 14). There is no essential shifting of the main bands depending on chemical composition of the Elga obertiite-related minerals.

The Raman spectra of the Elga aenigmatite-subgroup minerals show characteristic scattering peaks near 446, 530-533, 660-663 (strongest), 693 (shoulder), 890 (strong) and 1050-1051 cm-1 (Figure 15) resembling those of terrestrial aenigmatite [67]. The chemical similarity of the Elga aenigmatite and its Mg-analog does not indicate any essential difference in their Raman spectra.
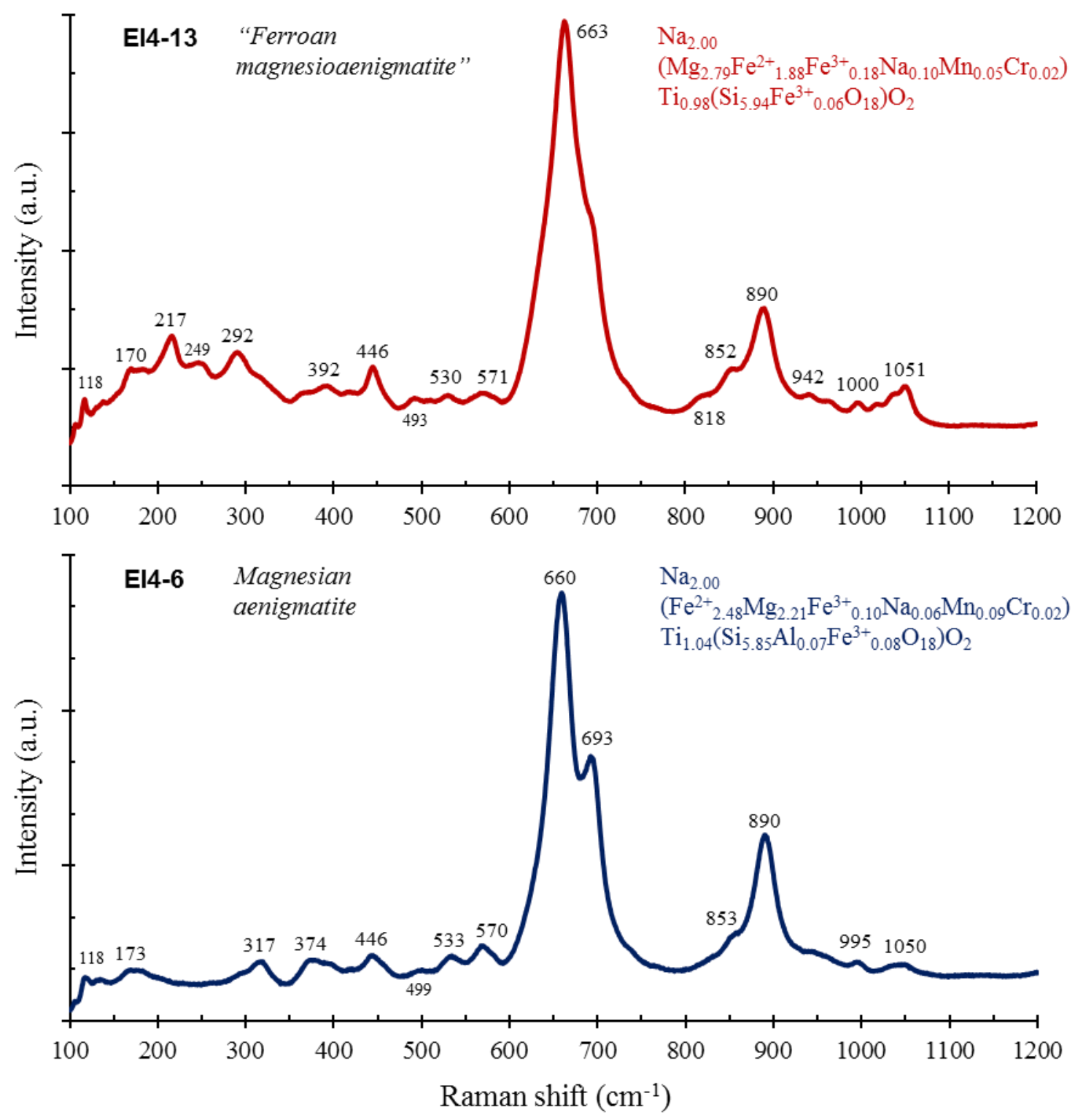

Figure 15. Raman spectra of the aenigmatite-subgroup minerals from the Elga-4 immiscible inclusion. 

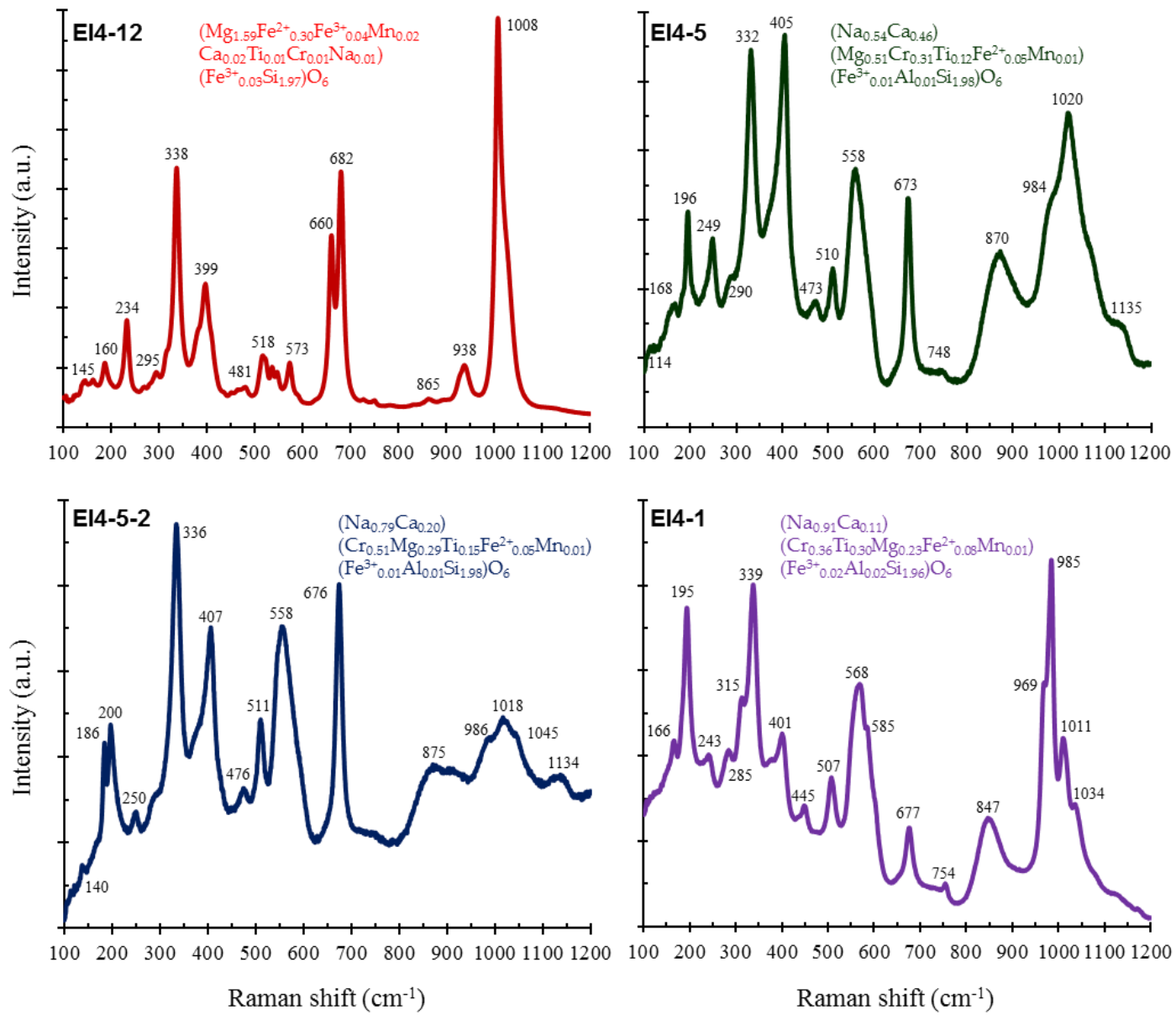

Figure 16. Raman spectra of enstatite and clinopyroxenes of the diopside-kosmochlor- $\mathrm{Na}\left(\mathrm{Mg}, \mathrm{Fe}_{0.5} \mathrm{Ti}_{0.5}\right.$ $\mathrm{Si}_{2} \mathrm{O}_{6}$ series from the Elga-4 immiscible inclusion.

Figure 16 display Raman data for the pyroxene-supergroup minerals in the Elga-4 immiscible inclusion (enstatite and clinopyroxenes of the diopside-kosmochlor- $\mathrm{Na}(\mathrm{Mg}, \mathrm{Fe})_{0.5} \mathrm{Ti}_{0.5} \mathrm{Si}_{2} \mathrm{O}_{6}$ series) with indication of their chemical composition. The enstatite spectrum shows bands suite common of low-Ca Mg-rich pyroxenes. Unfortunately, this spectrum does not give any information about structural features of the phase (monoclinic or orthorhombic symmetry). The Raman spectra of the Elga complex clinopyroxenes show the following characteristic bands (in $\mathrm{cm}^{-1}$ ): 195-200, 243-250, 332-339 (strongest), 401-407 (strong), 507-510, 558-568 (strong), 673-677 (strong), 870-875, 984-986; 1011-1020 (strong), 1034-1035 (Figure 16). Variable intensity and shifting of some Raman signals seem to record different chemical composition. The Raman spectra of meteoritic and terrestrial kosmochlor and diopside-kosmochlor have been reported in a few publications [54,56]. In general, the Elga clinopyroxene data presented here are quite similar to the published spectra for the Morasko iron meteorite [56].

The Raman spectra of the Na-Ca-Mg-Fe-orthophosphates, quartz, feldspars and siliceous glass are shown in Figures S13 and S14. Brianite, czochralskiite and marićite were analyzed within natrophosphate globule (Figure S13). In general, the data presented here for the Elga-4 orthophosphates are very similar to the Raman spectra for the holotype czochralskiite from the Morasko iron meteorite [58] and Na-rich phosphates from other silicate inclusions with immiscibility, found in the Elga meteorite [13]. The latter publication contains detailed interpretation of the Raman spectra for studied phosphates. The Raman spectra for the $\mathrm{SiO}_{2}$ phase in the Elga-4 inclusion are clearly shown that it is to be quartz (Figure S14) and not to be tridymite or cristobalite as it was assumed previously for the Elga silicate 
inclusions [8]. Unfortunately, Raman spectroscopy does not give any direct information about structural state of K-feldspar (orthoclase, microcline or sanidine) (Figure S14).

\section{Discussion and Concluding Remarks}

It is assumed that IIE irons have genetic relations to $\mathrm{H}$-chondrite-like bodies according to isotopic and geochemical characteristics [68-71]. The origin of fractionated IIE irons, including the Elga meteorite, is explained by a complex model evolving disruption and reassembly of partially molten asteroids and their complex impact history [15,69-71]. Silicate-bearing iron meteorites may be also explained by formation at the core-mantle boundary of small bodies due to separation of silicate and metal parts or by condensation of silicate and metal liquids in solar nebula (see review in $[13,15]$ ).

The previous and recent studies for the Elga IIE iron meteorite showed mineralogical diversity for silicate inclusions $[5,8-13,15,19]$. It is suggested that the modal and bulk compositions of glassy-containing silicate inclusions in the Elga meteorite and chemical composition of their phases are consistent with the model of $25 \%$ partial melting of $\mathrm{H}$-chondrite and subsequent equilibrium crystallization of this melt (with merrillite liquidus phase) and then quenching at about $1090^{\circ} \mathrm{C}$ [15]. However, this model does not explain the appearance of the silicate-phosphate liquid immiscibility observed in some Elga inclusions. It should be noted that in addition to the Elga meteorite meniscus-shaped Ca-Na-phosphate segregations are known within the silicate inclusions in the Colomera and Sombrerete iron meteorites [68-71].

The study of the Elga immiscible inclusions implies that silicate-natrophosphate immiscibility is a high-temperature process (probably $>1000-1100{ }^{\circ} \mathrm{C}$, quartz-feldspar eutectic). In the studied inclusion, the silicate vein cross-cuts the natrophosphate globule (Figure 7, Figure 9 and Figure S11) and this is evidence about earlier crystallization (or quenching) of natrophosphatic melt rather than silicate liquid. However, maximal PTX-conditions for separation of initial melt into silicate and natrophosphate components is not easy to evaluate. It is not excluded that this silicate inclusion was previously subjected to complete melting during shock event.

In general, the inclusions with silicate-natrophosphate immiscibility are rare type of silicate inclusions found in the Elga meteorite $[12,13,17]$ : about $8 \%$ of total inclusions based on Figure 2 . Such inclusions drastically differ from other types both in chemical composition (high abundance of $\mathrm{Na}$ and Ti) and exotic mineralogy. It is quite possible the appearance of Ti-rich silicates (oxyamphibole, aenigmatite, complex clinopyroxenes) and $\mathrm{Na}-\mathrm{Ca}-\mathrm{Mg}$-Fe-orthophosphates (brianite, czochralskiite, marićite) is strongly related to silicate-natrophosphate immiscibility within silicate inclusions in the Elga meteorite and maybe in other IIE meteorites.

The mineralogy of the studied immiscible inclusion revealed three potentially new mineral species: obertiite-related oxyamphibole $\mathrm{NaNa}_{2} \mathrm{Mg}_{3} \mathrm{Fe}^{2+}{ }_{0.5} \mathrm{Ti}_{1.5}\left[\mathrm{Si}_{8} \mathrm{O}_{22}\right] \mathrm{O}_{2}$, Mg-analog of aenigmatite $\mathrm{Na}_{2} \mathrm{Mg}_{5} \mathrm{TiSi}_{6} \mathrm{O}_{18} \mathrm{O}_{2}$ and Na-Ti-rich clinopyroxene $\mathrm{Na}\left(\mathrm{Mg}, \mathrm{Fe}_{0.5} \mathrm{Ti}_{0.5} \mathrm{Si}_{2} \mathrm{O}_{6}\right.$. Formula calculation for these phases was based on the traditional method: charge balance is due to division of total $\mathrm{FeO}$ into $\mathrm{FeO}$ and $\mathrm{Fe}_{2} \mathrm{O}_{3}$. In general, it seems to be correct because the Mössbauer spectroscopy for the Elga diopsidic clinopyroxene showed the high amount of $\mathrm{Fe}^{3+}(\approx 50 \%$ of total $\mathrm{Fe})$ [8]. In addition, the previous and recent data on mineral chemistry for the Elga meteorite also indicated the abundance of $\mathrm{Fe}^{3+}$ in silicates $[5,8,9,13,15,17,19]$. All this suggests a high oxygen fugacity during crystallization of silicate melt [8]. In the case of the Elga-4 immiscible inclusion, silicates are variable in the content of $\mathrm{Fe}^{3+}$ (in dependence of mineral position-silicate part, contact or phosphate globule), which suggests local variations in oxygen activity during crystallization. There are no strong evidences about highly reduced conditions during crystallization of the Elga-4 inclusion. It is assumed that all Ti in minerals is in tetravalent state, like in other silicate inclusions of the Elga meteorite containing rutile, ilmenite or panethite $[8,9,12,13,15]$. In general, the abundance of $\mathrm{Fe}^{3+}$ should be in hypothetical contradiction with the high content of $\mathrm{Ti}^{3+}$ (different oxygen fugacity conditions). Nevertheless, the presence of trivalent titanium in the Elga minerals, especially for potentially new mineral species found in this meteorite, 
may be suggested. The different variants of ideal compositions (with $\mathrm{Ti}^{4+}$ and $\mathrm{Ti}^{3+}$ ) for the above Elga oxyamphiboles and clinopyroxenes are presented in Table 9.

Table 9. Ideal compositions for some natural and hypothetical Na-rich oxyamphiboles and clinopyroxenes.

\begin{tabular}{|c|c|c|c|c|c|c|c|}
\hline Phase & $\begin{array}{c}\text { Ferri- } \\
\text { Obertiite }\end{array}$ & $\begin{array}{c}\text { "Ti }{ }^{3+}- \\
\text { Obertiite" }\end{array}$ & $\begin{array}{l}\text { "Fe } \mathrm{e}^{2+} \mathrm{Ti}^{4+} \\
\text { Obertiite" }\end{array}$ & $\begin{array}{l}\text { Kosmo- } \\
\text { Chlor }\end{array}$ & $\begin{array}{l}\text { "Ti }{ }^{3+}-\text { kosmo- } \\
\text { Chlor" }\end{array}$ & $\begin{array}{c}\text { “Ti" }{ }^{3+}-\mathrm{Na}- \\
\mathrm{Cpx}^{\prime}\end{array}$ & $\begin{array}{c}\text { "Mg-Ti }{ }^{4+}-\mathrm{Na}- \\
\mathrm{Cpx}^{\prime}\end{array}$ \\
\hline Formula & $\begin{array}{c}\mathrm{NaNa}_{2} \\
\mathrm{Mg}_{3} \mathrm{Fe}^{3+} \mathrm{Ti}^{4+} \\
\left(\mathrm{Si}_{8} \mathrm{O}_{22}\right) \mathrm{O}_{2}\end{array}$ & $\begin{array}{c}\mathrm{NaNa}_{2} \\
\mathrm{Mg}_{3} \mathrm{Ti}^{3+} \mathrm{Ti}^{4+} \\
\left(\mathrm{Si}_{8} \mathrm{O}_{22}\right) \mathrm{O}_{2}\end{array}$ & $\begin{array}{c}\mathrm{NaNa}_{2} \\
\mathrm{Mg}_{3} \mathrm{Fe}^{2+}{ }_{0.5} \mathrm{Ti}^{4+}{ }_{1.5} \\
\left(\mathrm{Si}_{8} \mathrm{O}_{22}\right) \mathrm{O}_{2}\end{array}$ & $\begin{array}{c}\mathrm{Na} \\
\mathrm{Cr} \\
\mathrm{Si}_{2} \mathrm{O}_{6}\end{array}$ & $\begin{array}{c}\mathrm{Na} \\
\mathrm{Cr}_{0.5} \mathrm{Ti}^{3+}{ }_{0.5} \\
\mathrm{Si}_{2} \mathrm{O}_{6}\end{array}$ & $\begin{array}{c}\mathrm{Na} \\
\mathrm{Ti}^{3+} \\
\mathrm{Si}_{2} \mathrm{O}_{6}\end{array}$ & $\begin{array}{c}\mathrm{Na} \\
\mathrm{Mg}_{0.5} \mathrm{Ti}^{4+}{ }_{0.5} \\
\mathrm{Si}_{2} \mathrm{O}_{6}\end{array}$ \\
\hline $\mathrm{SiO}_{2}$ & 56.27 & 58.03 & 56.53 & 52.90 & 55.60 & 58.59 & 56.88 \\
\hline $\mathrm{TiO}_{2}$ tot & 9.35 & 16.88 & 14.09 & 0.00 & 13.87 & 29.23 & 18.91 \\
\hline $\mathrm{Cr}_{2} \mathrm{O}_{3}$ & 0.00 & 0.00 & 0.00 & 33.46 & 17.58 & 0.00 & 0.00 \\
\hline $\mathrm{FeO}$ tot & 8.39 & 0.00 & 4.22 & 0.00 & 0.00 & 0.00 & 0.00 \\
\hline $\mathrm{MgO}$ & 14.15 & 14.60 & 14.22 & 0.00 & 0.00 & 0.00 & 9.54 \\
\hline $\mathrm{Na}_{2} \mathrm{O}$ & 10.88 & 11.22 & 10.93 & 13.64 & 14.34 & 15.11 & 14.67 \\
\hline Sum & 99.04 & 100.72 & 100.00 & 100.00 & 101.39 & 102.93 & 100.00 \\
\hline
\end{tabular}

$\mathrm{TiO}_{2}$ tot and $\mathrm{FeO}$ tot mean total titanium and iron oxides calculated as $\mathrm{TiO}_{2}$ and $\mathrm{FeO}$. $\mathrm{Cpx}$-clinopyroxene.

It should be noted that the occurrence of minerals containing $\mathrm{Ti}^{4+}$ or $\mathrm{Ti}^{3+}$ or both components is common of carbonaceous meteorites [24,72-80]. It is especially remarkable for the Allende meteorite, in which $\mathrm{Ti}^{4+}-\mathrm{Ti}^{3+}$-bearing minerals have been recently found: $\mathrm{Ti}^{3+}$-containing rhönite [73], tistarite $\mathrm{Ti}^{3+}{ }_{2} \mathrm{O}_{3}$ [74], grossmanite $\mathrm{CaTi}^{3+} \mathrm{AlSiO}_{6}$ [75], panguite $\left(\mathrm{Ti}^{4+}, \mathrm{Sc}, \mathrm{Al}, \mathrm{Mg}, \mathrm{Zr}, \mathrm{Ca}\right)_{1.8} \mathrm{O}_{3}$ [76], hutcheonite $\mathrm{Ca}_{3} \mathrm{Ti}^{4+}\left(\mathrm{SiO}_{4}\right)_{3}$ [77], paqueite $\mathrm{Ca}_{3} \mathrm{Ti}^{4+} \mathrm{Si}_{2}\left(\mathrm{Al}_{2} \mathrm{Ti}^{4+}\right) \mathrm{O}_{14}$ [78] and kaitianite $\mathrm{Ti}^{3+}{ }_{2} \mathrm{Ti}^{4+} \mathrm{O}_{5}$ [80].

Thus, the mineralogy of the Elga inclusion with silicate-natrophosphate immiscibility first outlines three potentially new Ti-rich minerals according to the $50 \%$ rule of IMA: obertiite-related oxyamphibole, Mg-analog of aenigmatite and Na-Ti-rich clinopyroxene. However, they need further detailed studies of both the crystal structure and chemical composition. These minerals should be carefully checked for the real concentrations and valence state of titanium and iron.

Supplementary Materials: The following figures are available online at http://www.mdpi.com/2075-163X/10/ 5/437/s1: Figure S1: Elemental maps for the area of local impact melting and further quenching in the Elga metal; Figure S2: BSE images and elemental maps for the area of surface alteration, Elga meteorite; Figure S3: BSE images and elemental maps for silicate inclusion Elga-1; Figure S4: BSE images for areas in silicate inclusions Elga-6 and Elga-11; Figure S5: BSE images and elemental maps for silicate inclusion Elga-5; Figure S6: BSE images and elemental maps for silicate inclusion Elga-8 enriched in troilite; Figure S7: Relationships of the obertiite-group mineral and aenigmatite in silicate part of immiscible inclusion Elga-4 (BSE image and elemental maps); Figure S8: Relationships of minerals in silicate part of immiscible inclusion Elga-4 (BSE image and elemental maps); Figure S9: BSE image and elemental maps for secondary phases from immiscible inclusion Elga-4; Figure S10: BSE images and elemental maps for chromite and related minerals on the contact between silicate and natrophosphate parts of immiscible inclusion Elga-4; Figure S11: Relationships of minerals in natrophosphate globule of immiscible inclusion Elga-4 (BSE image and elemental maps); Figure S12: BSE image and elemental maps for the silicate-natrophosphate contact in the immiscible inclusion Elga-4; Figure S13: Raman spectra of Na-rich orthophospates from natrophosphate globule in the Elga-4 immiscible inclusion; Figure S14: Raman spectra of quartz, glasses and feldspars from the Elga-4 immiscible inclusion.

Author Contributions: V.V.S. wrote the paper, performed the mineralogical description, measurements of chemical composition (EMPA, SEM) and Raman studies for minerals of the immiscible inclusion in the Elga meteorite. The author has read and agreed to the published version of the manuscript.

Funding: The investigations were partly supported by the State assignment project (IGM SD 0330-2016-0005). This work was also supported by the Initiative Project of Ministry of Science and Higher Education of the Russian Federation and by Act 211 of the Government of the Russian Federation, agreement no. 02.A03.21.0006.

Acknowledgments: The author would like to thank E.N. Nigmatulina, N.S. Karmanov and M.V. Khlestov (IGM) for technical assistance at EMPA and SEM studies. We are highly appreciative of the valuable comments and suggestions of three anonymous reviewers.

Conflicts of Interest: The authors declare no conflict of interest. 


\section{References}

1. Plyashkevich, L.N. Some data regarding the composition and structure of the iron meteorite Elga. Meteoritika 1962, 22, 51-60. (In Russian)

2. Vronskii, V.I. On the find of the Elga iron meteorite. Meteoritika 1962, 22, 47-50. (In Russian)

3. D'yakonova, M.I.; Kharitonova, V.Y. Composition of Ni-rich iron from some iron and iron-stone meteorites of different types. Meteoritika 1963, 23, 42-43. (In Russian)

4. Wasson, J.T. Ni, Ga, Ge and Ir in the metal of iron meteorites with silicate inclusions. Geochim. Cosmochim. Acta 1970, 34, 957-964. [CrossRef]

5. Kvasha, L.G.; Lavrent'ev, Y.G.; Sobolev, N.V. Silicate inclusions and evidence of impact metamorphism in the Elga octahedrite. Meteoritika 1974, 33, 143-147. (In Russian)

6. Kashkarov, L.L.; Korotkova, N.N.; Lavrukhina, A.V. Relict radiation by cosmic rays low-energy heavy nuclei of matter of iron meteorite. Dokl. Acad. Nauk SSSR 1975, 221, 198-200. (In Russian)

7. D'yakonova, M.I.; Kharitonova, V.Y.; Anvel, A.A. Chemical Composition of Meteorites; Nauka: Moscow, Russia, 1979. (In Russian)

8. Osadchii, E.G.; Baryshnikova, G.V.; Novikov, G.V. The Elga meteorite: Silicate inclusions and shock metamorphism. Proc. Lunar Planet. Sci. 1981, 12, 1049-1068.

9. Sharygin, I.S. Mineralogy of the Elga meteorite. In Thesis for the Bachelor of Science; Department of Geology and Geophysics, Novosibirsk State University: Novosibirsk, Russia, 2005; p. 32. (In Russian)

10. Teplyakova, S.N.; Khisina, N.R.; Artemov, V.V.; Vasil'ev, A.L. Nanomineralogy of dendritic inclusions in the Elga iron meteorite. Zap. Ross. Mineral. O-va 2012, 141, 42-52. (In Russian)

11. Nazarov, M.A.; Teplyakova, S.N.; Brandstaetter, F.; Ntaflos, T. Fluorine-bearing merrillite from a silicate inclusion of the Elga (IIE) iron meteorite. Lunar Planet. Sci. Conf. 2013, 44, 1342.

12. Sharygin, V.V. Phosphate minerals in silicate inclusions of the Elga meteorite. In 5th Conference "Meteorites, Asteroids, Comets"; PH Fort Dialog-Iset': Ekaterinburg, Russia, 2017; pp. 153-157. (In Russian)

13. Litasov, K.D.; Podgornykh, N.M. Raman spectroscopy of various phosphate minerals and occurrence of tuite in the Elga IIE iron meteorite. J. Raman Spectrosc. 2017, 48, 1518-1527. [CrossRef]

14. Khisina, N.R.; Teplyakova, S.N.; Wirth, R.; Senin, V.G.; Averin, A.A.; Shiryaev, A.A. Carbon-bearing phases in shock-induced melt zones of the Elga meteorite. Geochem. Inter. 2017, 55, 317-329. [CrossRef]

15. Teplyakova, S.N.; Lorenz, C.A.; Ivanova, M.A.; Kononkova, N.N.; Anosova, M.O.; Ryazantsev, K.M.; Kostitsyn, Y.A. Mineralogy of silicate inclusions in the Elga IIE iron meteorite. Geochem. Inter. 2018, 56, 1-23. [CrossRef]

16. Senin, V.G.; Zinovieva, N.G.; Pankrushina, E.A.; Averin, A.A.; Khisina, N.R. Identification of minerals in shock melted regions in meteorite Elga. Exp. Geosci. 2018, 24, 47-49.

17. Sharygin, V.V. Mineralogy of inclusion with silicate-natrophosphate immiscibility, meteorite Elga (IIE). Meteorit. Planet. Sci. 2018, 53, 6013.

18. Teplyakova, S.N.; Lorenz, C.A. Metal crystallization in IIE irons and their possible meteorite analogues. Geochem. Inter. 2019, 57, 893-902. [CrossRef]

19. Khisina, N.R.; Wirth, R.; Abdrakhimov, A.M. Liquid immiscibility in regions of localized shock-induced melting in the Elga meteorite. Geochem. Inter. 2019, 57, 903-911. [CrossRef]

20. Litasov, K.D.; Teplyakova, S.N.; Shatskiy, A.; Kuper, K.E. Fe-Ni-P-S melt pockets in Elga IIE iron meteorite: Evidence for the origin at high-pressures up to $20 \mathrm{GPa}$. Minerals 2019, 9, 616. [CrossRef]

21. Wasson, J.T.; Wang, J. A nonmagmatic origin of group-IIE iron meteorites. Geochim. Cosmochim. Acta 1986, 50, 725-732. [CrossRef]

22. Wasson, J.T. Formation of non-magmatic iron-meteorite group IIE. Geochim. Cosmochim. Acta 2017, 53, 396-416. [CrossRef]

23. Pouchou, I.L.; Pichoir, F. “PaP” (phi-rho-z) procedure for improved quantitative microanalysis. In Microbeam Analysis; Armstrong, I.T., Ed.; San Francisco Press: San Francisco, CA, USA, 1985; pp. 104-106.

24. Rubin, A.E.; Ma, C. Meteoritic minerals and their origins. Chem. Erde 2017, 77, 325-385. [CrossRef]

25. Floran, R.; Prinz, M.; Hlava, P.; Keil, K.; Nehru, C.; Hinthorne, J. The Chassigny meteorite: A cumulate dunite with hydrous amphibole-bearing melt inclusions. Geochim. Cosmochim. Acta 1978, 42, 1213-1229. [CrossRef]

26. Treiman, A.H. Amphibole and hercynite spinel in Shergotty and Zagami: Magmatic water, depth of crystallization, and metasomatism. Meteoritics 1985, 20, 229-243. [CrossRef] 
27. Johnson, M.C.; Rutherford, M.J.; Hess, P.C. Chassigny petrogenesis: Melt compositions, intensive parameters and water contents of Martian (?) magmas. Geochim. Cosmochim. Acta 1991, 55, 349-366. [CrossRef]

28. Ikeda, Y. Petrology of magmatic silicate inclusions in the Allan Hills 77005 lherzolitic shergottite. Meteorit. Planet. Sci. 1998, 33, 803-812. [CrossRef]

29. Monkawa, A.; Mikouchi, T.; Koizumi, E.; Sugiyama, K.; Miyamoto, M. Determination of the Fe oxidation state of the Chassigny kaersutite: A microXANES spectroscopic study. Meteorit. Planet. Sci. 2006, 41, 1321-1329. [CrossRef]

30. Hagen, E. A Comparative Study of Kaersutite in the Egersund Dikes and SNC Meteorites. Master's Thesis, Ohio State University, Columbus, OH, USA, 2017.

31. Ivanov, A.V.; Kononkova, N.N.; Zolensky, M.E.; Migdisova, L.F.; Stroganov, I.A. The Kaidun meteorite: A large albite crystal-fragment of an alkaline rock. Lunar Planet. Sci. 2001, 32, 1080.

32. Hawthorne, F.C.; Oberti, R.; Harlow, G.E.; Maresch, W.V.; Martin, R.F.; Schumacher, J.C.; Welch, M.D. Nomenclature of the amphibole supergroup. Am. Mineral. 2012, 97, 2031-2048. [CrossRef]

33. Oberti, R.; Cannillo, E.; Toscani, G. How to name amphiboles after the IMA2012 report: Rules of thumb and a new PC program for monoclinic amphiboles. Period. Mineral. 2012, 81, 257-267. [CrossRef]

34. Hawthorne, F.C.; Oberti, R.; Zanetti, A.; Czamanske, G.K. The role of Ti in hydrogen-deficient amphiboles: Sodic-calcic and sodic amphiboles from Coyote Peak, California. Can. Mineral. 1998, 36, 1253-1265.

35. Hawthorne, F.C.; Cooper, M.A.; Grice, J.D.; Ottolini, L. A new anhydrous amphibole from the Eifel region, Germany: Description and crystal structure of obertiite, $\mathrm{NaNa}\left(\mathrm{Mg}_{3}, \mathrm{Fe}^{3}+, \mathrm{Ti}^{4+}\right) \mathrm{Si}_{8} \mathrm{O}_{22} \mathrm{O}_{2}$. Am. Mineral. 2000, 85, 236-241. [CrossRef]

36. Hawthorne, F.C.; Ball, N.A.; Czamanske, G.K. Ferro-obertiite, $\mathrm{NaNa}_{2}\left(\mathrm{Fe}^{2+}{ }_{3} \mathrm{Fe}^{3+} \mathrm{Ti}\right) \mathrm{Si}_{8} \mathrm{O}_{22} \mathrm{O}_{2}$, new mineral of the amphibole group from Coyote Peak, Humboldt County, California. Can. Mineral. 2010, 48, 301-306. [CrossRef]

37. Oberti, R.; Boiocchi, M.; Hawthorne, F.C.; Ball, N.A.; Blass, G. Ferri-obertiite from the Rothenberg quarry, Eifel volcanic complex (Germany): Mineral data and crystal-chemistry of a new amphibole end-member. Mineral. Mag. 2017, 81, 641-651. [CrossRef]

38. Kullerud, K.; Zozulya, D.; Erambert, M.; Ravna, E.J.K. Solid solution between potassic alkali amphiboles from the silica-rich Kvaløya lamproite, West Troms Basement Complex, northern Norway. Eur. J. Mineral. 2014, 25, 935-945. [CrossRef]

39. Oberti, R.; Ungaretti, L.; Cannillo, E.; Hawthrone, F. The behavior of Ti in amphiboles: I. Four- and six-coordinated Ti in richterite. Eur. J. Mineral. 1992, 4, 425-439. [CrossRef]

40. Kunzmann, T. The aenigmatite-rhönite mineral group. Eur. J. Mineral. 1999, 11, 743-756. [CrossRef]

41. Grew, E.S.; Hålenius, U.; Pasero, M.; Barbier, J. Recommended nomenclature for the sapphirine and surinamite groups (sapphirine supergroup). Mineral. Mag. 2008, 72, 839-876. [CrossRef]

42. Brearley, A.J.; Jones, R.H. Chondritic Meteorites. In Planetary Materials; Papike, J.J., Ed.; Mineralogical Society of America: Washington, DC, USA, 1998; Volume 3, p. 398.

43. Zolensky, M.; Ivanov, A. The Kaidun microbreccia meteorite: A harvest from the inner and outer asteroid belt. Geochemistry 2003, 63, 185-246. [CrossRef]

44. Sokol, A.K.; Bischoff, A.; Marhas, K.K.; Mezger, K.; Zinner, E. Late accretion and lithification of chondritic parent bodies: $\mathrm{Mg}$ isotope studies on fragments from primitive chondrites and chondritic breccias. Meteorit. Planet. Sci. 2007, 42, 1291-1308. [CrossRef]

45. Price, R.C.; Johnson, R.W.; Gray, C.M.; Frey, F.A. Geochemistry of phonolites and trachytes from the summit region of Mt. Kenya. Contrib. Mineral. Petrol. 1985, 89, 394-409. [CrossRef]

46. Starikova, A.E.; Sklyarov, E.V.; Kanakin, S.V. Mg-aenigmatite from the Tazheran massif (East Siberia, Russia). In Proceedings of the Goldschmidt 2013 Conference Abstracts, Florence, Italy, 25-30 August 2013; p. 2253.

47. Morimoto, N.; Fabries, J.; Ferguson, A.K.; Ginzburg, I.V.; Ross, M.; Seibert, F.A.; Zussman, J.; Aoki, K.; Gottardi, G. Nomenclature of pyroxenes. Mineral. Mag. 1988, 52, 535-550. [CrossRef]

48. Frondel, C.; Klein, C., Jr. Ureyite, $\mathrm{NaCr}_{2} \mathrm{Si}_{2} \mathrm{O}_{6}$, a new meteoritic pyroxene. Science 1965, 149, $742-744$. [CrossRef] [PubMed]

49. Greshake, A.; Bischoff, A. Chromium-bearing phases in Orgueil (CI): Discovery of magnesiochromite $\left(\mathrm{MgCr}_{2} \mathrm{O}_{4}\right)$, ureyite $\left(\mathrm{NaCrSi}_{2} \mathrm{O}_{6}\right)$, and chromium oxide $\left(\mathrm{Cr}_{2} \mathrm{O}_{3}\right)$. Lunar Planet. Sci. 1996, $27,461$.

50. Sobolev, V.S.; Sobolev, N.V.; Lavrentiev, U.G. Chrome-rich clinopyroxenes from the kimberlities of Yakutia. Neues Jahrb. für Mineral. 1975, 123, 213-218. 
51. Mével, C.; Kiénast, J.-R. Jadeite-kosmochlor solid solution and chromian sodic amphiboles in jadeitites and associated rocks from Taw maw (Burma). Bull. Minéral. 1986, 109, 617-633. [CrossRef]

52. Secco, L.; Martignago, F.; Dal Negro, A.; Reznitskii, L.Z.; Sklyarov, E.V. Crystal chemistry of $\mathrm{Cr}^{3+}-\mathrm{V}^{3+}-\mathrm{rich}^{-}$ clinopyroxenes. Am. Mineral. 2002, 87, 709-714. [CrossRef]

53. Reznitsky, L.Z.; Sklyarov, E.V.; Galuskin, E.V. Complete isomorphic join diopside-kosmochlor $\mathrm{CaMgSi}_{2} \mathrm{O}_{6}-$ $\mathrm{NaCrSi}_{2} \mathrm{O}_{6}$ in metamorphic rocks of the Sludyanka complex (southern Baikal region). Rus. Geol. Geophys. 2011, 52, 40-51. [CrossRef]

54. Franz, L.; Sun, T.T.; Hänni, H.A.; de Capitani, C.; Thanasuthipitak, T.; Atichat, W. A comparative study of jadeite, omphacite and kosmochlor jades from Myanmar, and suggestions for a practical nomenclature. J. Gemmol. 2014, 34, 210-229. [CrossRef]

55. Krátký, O.; Rapprich, V.; Racek, M.; Míková, J.; Magna, T. On the chemical composition and possible origin of $\mathrm{Na}-\mathrm{Cr}$-rich clinopyroxene in silicocarbonatites from Samalpatti, Tamil Nadu, South India. Minerals 2018, 8, 355. [CrossRef]

56. Karwowski, Ł.; Helios, K.; Kryza, R.; Muszyński, A.; Drożdżewski, P. Raman spectra of selected mineral phases of the Morasko iron meteorite. J. Raman Spectrosc. 2013, 44, 1181-1186. [CrossRef]

57. Karwowski, Ł.; Kusz, J.; Muszyński, A.; Kryza, R.; Sitarz, M.; Galuskin, E.V. Moraskoite, $\left.\mathrm{Na}_{2} \mathrm{Mg}_{(\mathrm{PO}}\right) \mathrm{F}$, a new mineral from the Morasko IAB-MG iron meteorite (Poland). Mineral. Mag. 2015, 79, 387-398. [CrossRef]

58. Karwowski, Ł.; Kryza, R.; Muszyński, A.; Kusz, J.; Helios, K.; Drożdżewski, P.; Galuskin, E.V. Czochralskiite, $\mathrm{Na}_{4} \mathrm{Ca}_{3} \mathrm{Mg}\left(\mathrm{PO}_{4}\right)_{4}$, a second new mineral from the Morasko IAB-MG iron meteorite (Poland). Eur. J. Mineral. 2016, 28, 890-899. [CrossRef]

59. Fuchs, L.H.; Olsen, E.; Henderson, E.P. On the occurrence of brianite and panethite, two new phosphate minerals from the Dayton meteorite. Geochim. Cosmochim. Acta 1967, 31, 1711-1719. [CrossRef]

60. Sturman, B.D.; Mandarino, J.A.; Corlett, M.I. Marićite, a sodium iron phosphate, from the Big Fish River area, Yukon Territory, Canada. Can. Mineral. 1977, 15, 396-398.

61. Kracher, A.; Kurat, G.; Buchwald, V.F. Cape York: The extraordinary mineralogy of an ordinary iron meteorite and its implications for the genesis of IIIAB irons. Geochem. J. 1977, 11, 207-217. [CrossRef]

62. Lauretta, D.S.; Buseck, P.R.; Zega, T.J. Opaque minerals in the matrix of the Bishunpur (LL3.1) meteorite: Constraints on the chondrule formation environment. Geochim. Cosmochim. Acta 2001, 65, 1337-1353. [CrossRef]

63. Barth, M.I.F.; Harries, D.; Langenhorst, F.; Hoppe, P. Sulfide-oxide assemblages in Acfer 094-Clues to nebular metal-gas interactions. Meteorit. Planet. Sci. 2018, 53, 187-203. [CrossRef]

64. Fornero, E.; Allegrina, M.; Rinaudo, C.; Mazziotti-Tagliani, S.; Gianfagna, A. Micro-Raman spectroscopy applied on oriented crystals of fluoro-edenite amphibole. Period. Mineral. 2008, 77, 5-14. [CrossRef]

65. Apopei, A.I.; Buzgar, N. The Raman study of amphiboles. An. Ştiinţifice Univ. Al. I. Cuza Iaşi Geol. 2010, 56, 57.

66. Leissner, L. Crystal chemistry of amphiboles studied by Raman spectroscopy. Master's Thesis, Mineralogisch-Petrographisches Institut, Universität Hamburg, Hamburg, Germany, 2014; p. 53.

67. Lafuente, B.; Downs, R.T.; Yang, H.; Stone, N. The power of databases: The RRUFF project. In Highlights in Mineralogical Crystallography; Armbruster, T., Danisi, R.M., Eds.; W. de Gruyter GmbH: Berlin, Germany, 2016; pp. 1-29. [CrossRef]

68. Buchwald, V. Handbook of Iron Meteorites; University of California Press: Berkeley, CA, USA, 1975; p. 1418.

69. Bogard, D.D.; Garrison, D.H.; McCoy, T.J. Chronology and petrology of silicates from IIE iron meteorites: Evidence of complex parent body evolution. Geochim. Cosmochim. Acta 2000, 64, 2133-2154. [CrossRef]

70. Ruzicka, A.; Hutson, M.; Floss, C. Petrology of silicate inclusions in the Sombrerete ungrouped iron meteorite: Implications for the origins of IIE-type silicate-bearing irons. Meteorit. Planet. Sci. 2006, 41, 1797-1831. [CrossRef]

71. Ruzicka, A. Silicate-bearing iron meteorites and their implications for the evolution of asteroidal parent bodies. Chem. Erde 2014, 74, 3-48. [CrossRef]

72. Beckett, J.R.; Live, D.; Tsay, F.D.; Grossman, L.; Stolper, E. $\mathrm{Ti}^{3+}$ in meteoritic and synthetic hibonite. Geochim. Cosmochim. Acta 1988, 52, 1479-1495. [CrossRef]

73. Bonaccorsi, E.; Merlino, S.; Pasero, M. Rhönite: Structure and microstructural features, crystal chemistry and polysomatic relationships. Eur. J. Mineral. 1990, 2, 203-218. [CrossRef] 
74. Ma, C.; Rossman, G.R. Tistarite, $\mathrm{Ti}_{2} \mathrm{O}_{3}$, a new refractory mineral from the Allende meteorite. Am. Mineral. 2009, 94, 841-844. [CrossRef]

75. Ma, C.; Rossman, G.R. Grossmanite, $\mathrm{CaTi}^{3+} \mathrm{AlSiO}_{6}$, a new pyroxene from the Allende meteorite. Am. Mineral. 2009, 94, 1491-1494. [CrossRef]

76. Ma, C.; Tschauner, O.; Beckett, J.R.; Rossman, G.R.; Liu, W. Panguite, $\left(\mathrm{Ti}^{4+}, \mathrm{Sc}, \mathrm{Al}, \mathrm{Mg}, \mathrm{Zr}, \mathrm{Ca}\right)_{1.8} \mathrm{O}_{3}$, a new ultra-refractory titania mineral from the Allende meteorite: Synchrotron micro-diffraction and EBSD. Am. Mineral. 2012, 97, 1219-1225. [CrossRef]

77. Ma, C.; Krot, A.N. Hutcheonite, $\mathrm{Ca}_{3} \mathrm{Ti}_{2}\left(\mathrm{SiAl}_{2}\right) \mathrm{O}_{12}$, a new garnet mineral from the Allende meteorite: An alteration phase in a Ca-Al-rich inclusion. Am. Mineral. 2014, 99, 667-670. [CrossRef]

78. Ma, C. Paqueite, IMA 2013-053. CNMNC Newsletter No. 17, October 2013, page 3002. Mineral. Mag. 2013, 77, 2997-3005.

79. Ma, C.; Yoshizaki, T.; Nakamura, T.; Muto, J. Rubinite, IMA 2016-110. CNMNC Newsletter No. 36, April 2017, page 408. Mineral. Mag. 2017, 81, 403-409.

80. Ma, C. Kaitianite, IMA 2017-078. CNMNC Newsletter No. 42, April 2018, page 450. Mineral. Mag. 2018, 82, 445-451.

(C) 2020 by the author. Licensee MDPI, Basel, Switzerland. This article is an open access article distributed under the terms and conditions of the Creative Commons Attribution (CC BY) license (http://creativecommons.org/licenses/by/4.0/). 